\title{
Computational analysis of Turkish makam music: review of state-of-the-art and challenges
}

\author{
Barış Bozkurt $^{1}$, Ruhi Ayangil ${ }^{2}$, Andre Holzapfel ${ }^{1}$
}

1) Bahçeşehir University, Electrical and Electronics Engineering Department, Beşiktaş, İstanbul

2) Fatih University, Türk Müziği Konservatuarı, Büyükçekmece, İstanbul

baris.bozkurt@bahcesehir.edu.tr, ruhi@ayangil.org,xyzapfel@gmail.com

[This is an Author's Original Manuscript of an Article whose final and definitive form, the Version of

Record, has been published in the Journal of New Music Research, Volume 43, Issue 1, 31 Mar

2014, available online at: http://dx.doi.org/10.1080/09298215.2013.865760]

\begin{abstract}
This text targets a review of the computational analysis literature for Turkish makam music, discussing in detail the challenges involved and presenting a perspective for further studies. For that purpose, the basic concepts of Turkish makam music and the description of melodic, rhythmic and timbral aspects are considered in detail. Studies on tuning analysis, automatic transcription, automatic melodic analysis, automatic makam and usul detection are reviewed. Technological and data resource needs for further advancement are discussed and available sources are presented.
\end{abstract}

\section{Introduction}

While being an unexplored domain by most of the musicologists and musicians today, computational analysis of music provides increasingly promising methods, thanks to advancements in the field of information retrieval, signal processing, and statistical analysis. Given the data storage capabilities, computational power of our personal computers and the amount of accessible data and tools on the internet, the limits of computational analysis are stretched far beyond what was thinkable 30 years ago.

Automatic computational analysis facilitates detection and analysis of information that would be too time-consuming to do manually. As an example, we can think of discovering all songs in a large collection that contain a specific melodic motif. Computational analysis finds use in many music technology applications such as music discovery and recommendation systems. Recently, the focus of computational analysis on Eurogenetic music is extending to include music of other cultures and involve culture specific knowledge in the design of methodologies. Serra (2011, 2013) presents review of the current paradigms in computational analysis and discusses the potential of including domain specific knowledge for further improvement and extension of the impact as well as a road map for future research (Serra et al, 2013). While the number of studies in the field of computational (ethno-) musicology (Tzanetakis, Kapur, Schloss, \& M. Wright, 2007) is increasing with a positive acceleration, studies of Turkish makam music ${ }^{1}$ that involve computational methods are still rare. A review of current

\footnotetext{
${ }^{1}$ The term "makam" mainly refers to a modality system and is used in many genres (like folk, art and various popular music genres). Here, we mainly consider the Ottoman/Turkish traditional/classical/art music ('geleneksel/klasik
} 
state-of-the-art is targeted here that gathers basic concepts, available tools and data, potentials and challenges, and a perspective for further research. For practical reasons, the review is limited to computational studies on Turkish makam music. Turkish makam music shares concepts, terminology and the practices with music of a large geographical region of northern African and Asian countries, especially that of Near East (Stubbs, 1994, pp.2). This review will potentially be useful for computational studies on other makam traditions.

Our paper is structured as follows; First, a review of basic concepts of Turkish makam music is presented in Section 2. Following the theoretical part, a review of computational studies for melodic description, rhythmic description and timbre is presented in Section 3. Section 4 is dedicated to discussing future directions and available resources for further advancements.

\section{Makam music theory, practice and their relation}

\subsection{The makam concept in Turkish music}

In this section, we target providing a brief introduction to Turkish makam music basic concepts ${ }^{2}$. Interested readers are referred to the following texts in English, some of which include in-depth study of basic terminology based on detailed analysis of literature as well as personal communication with many masters of makam music. (Stubbs, 1994, Popescu-Judetz, 1996, Ayangil, 2008, K. L. Signell, 2008, Ederer, 2011, Aydemir, 2010, Öztürk, 2011). A glossary section is provided at the end of this paper to help the reader follow text containing some specific terms.

A large list of descriptions is available for the makam concept. Some examples are: "Makam is a process of occurrence. It is a specific form of a musical scale that characterizes itself by an organization of intervals and various constitutive relations" (Yekta, 1924 ${ }^{3}$ ), "the feature that is created by the relation of pitches of a scale or melody and the tonic and/or dominant" (Arel, 1968), "the çeşni (flavor/taste) ${ }^{4}$ that is created by melodic phrases that are seyir (melodic progression) rules within a scale." (Karadeniz, 1980), "Makam, before everything else, is based on a scale. Makam is a progression that gives the makam a life by starting from somewhere of the seyir, moving towards the güçlü and going towards karar.", (Gürmeriç, 1966), "a practical melody theory, grouping melodies by families or categories that are distinguished by the use of careful microtonal inflections of certain tones according to custom, together with idealized notions of melodic contour" (Stubbs, 1994, pp 1). As for many concepts in music, bare definitions or descriptions provide very limited insight. More definitions and a review of makam music theories are available in (Can, 1993, Ayangil, 2001).

An interesting global view on the concept of makam/maqam is in the context of modal practice as described by Powers and Wiering (Powers, H. S. \& Wiering, F. (n.d.)). Makam can be interpreted as a mode in the sense of a particularized scale or generalized tune, hence something in middle of the

Osmanl1/Türk (sanat) musikisi') and exclude folk and popular genres, while most of our discussions would still find some relevance for these excluded genres. When we provide analysis results to demonstrate an approach, the data sets used include pieces from a time span of 3-4 centuries from composers like Itri, İsmail Dede Efendi, Hac1 Arif Bey, Tanburi Cemil Bey and Sadettin Kaynak.

${ }^{2}$ We use the spelling "makam" here, which is used in Turkey, because we mainly refer to the concepts of music traditions practiced nowadays in Turkey.

${ }^{3}$ Yekta cites the following reference for this definition: Dechevrens, A. (1898). Etudes de science musicale. 1-11, Paris.

${ }^{4}$ The terms like çeşni, güçlü, karar and seyir are explained in various sections of the text. In addition short descriptions are provided in the glossary section at the end. 
continuum spanned by scale and tune on its two poles. Within that theoretical framework, Ruth Davis gives a concise interpretation of several aspects of makam, such as the construction of its scale, the melodic progression, seyir (Davis, n. d.). Touma explains that the fixed "tonal-spatial" (or tonaltemporal) organization is the most essential feature of the maqam phenomenon (Touma, 1971, pp. 2).

It is considered that one of the early uses of the term "makam" is in the texts of Abdülkadir Merâgî (1360 - 1435) (Bardakç1, 1986). Out of the context of music, the word makam also refers to a "location", a "state" or a " (hierarchical) position". Öztürk considers that the meaning of makam as "position" refers to the position (of melodies) on the instrument for an instrumentalist (Öztürk, 2011). This approach links the makam concept to a melodic progression emphasizing (or melodic organization around) a certain note of the scale (or a fret/position on the instrument). For a majority of the makamlar (plural of makam), a melodic progression starts around a certain tonal center or an emphasis note ${ }^{5}$ and a group of notes that surround it (usually within the range of a tri-chord below and a tri/tetra-chord above) play an important role in the progression. Öztürk (2011) compares historical texts, and discusses how various musical concepts in defining the concept of makam stem from basically two different conceptualizations; "a scale-centered approach" and "a melody-centered approach".

Davis considers that the modal meanings of makam/maqam "derive from a basic meaning of 'tone' or "degree of the scale" and had replaced the older Persian terms pardeh (perde in Turkish, referring both to note and fret) and shedd in $15^{\text {th }}$ century Ottoman treatises (Davis, n.d.). A composition emphasizes certain degrees of the scale with specific tri/tetra/penta-chords, and progresses towards the end by emphasizing the karar. Turkish musicians consider such melodies as having a specific "flavor" or "taste", which is reflected by their use of the term çeşni. The art of makam music lies in forming a progression through melodic phrases that leads to a colorful collection of çeşni's that is coherent within a certain makam. For example, an over-emphasis of a certain çeşni may be considered to be not typically related with a certain makam.

As Ederer states: "Flavor/Çeşni literally means "a taste" or "a sample" of something, and it generally covers any melodic material that can identify a particular makam as such. In this sense the most succinct definition was given to me by Özer Özel, who called çeşni "the smallest melodic concept conveying the explanatory (identifying) power of a makam". (Ederer, 2011, pp. 149) We encounter the problem that the term çeşni is used in an ambiguous way by performers of makam music (Ederer, 2011, pp. 152); while some seem to apply it in the sense of a modulation as a change in the structure of the scale, others apply it to melodic phrases that use notes that are considered part of the makam.

The seyir (of a makam) can also be considered to follow a certain structure when considering the composition as a unit. The sections of seyir are: zemin (introduction and first cadenza ${ }^{6}$ ), meyan (development) and karar (resolution to the karar pitch). This structure can be observed in many compositions such as the instrumental improvisation (taksim), or the most popular vocal form şarkl. It should be pointed out that it is not related to a ternary A-B-A form, where the beginning part is picked up again in the final part. It is rather that seyir starts with introducing the specific makam, steps away from it, and then modulates back to it to find the karar, often without clear repetition of motivic content.

\footnotetext{
${ }^{5}$ While for basic makamlar the opening (i.e. constructing initial melodies around a central emphasis note) is fixed, more than one alternative opening exists for some compound makamlar as pointed by Tanrikorur (Tanr1korur, 2003): the famous composer Hac1 Arif Bey (1831-1885) had used 5 different openings in makam Kürdilihicazkar.

${ }^{6}$ Most often the term cadence/cadenza is used to refer to resolution by various Turkish musicians such as Aydemir (2010).
} 
There are approximately 15-20 basic makamlar and many others are created by combined use of these basic makamlar. The Turkish makam system is open-ended and non-hierarchical (Davis, n.d). While the number of makamlar are claimed to be more than 600, today, we don't have access to any pieces in more than 300 of these makamlar. A statistical analysis of TRT (Turkish-Radio-Television) repertoire of 23592 pieces shows that the number of makamlar with more than 10 pieces is 120 , while $72 \%$ of the pieces is in 20 makamlar (Çevikoğlu, 2007). Çevikoğlu reports the sorted listed of top ten makamlar in terms of the coverage of the repertoire as: Hicaz (2359 pieces), Nihavent (2273 p.), Hüzzam (1408 p.), Rast (1344 p.), Kürdilihicazkar (1275 p.), Uş̧̧ak (1242 p.), Hüseyni (987 p.), Mahur (664 p.), Muhayyer-Kürdi (614 p.) and Hicazkar (605 p.).

\section{2 Tuning and notation}

The tuning system for makam music has been studied by many theoreticians starting by Al-Kindi (9th century) who proposed Pythagorean pitch ratios for Ud fingerings ${ }^{7}$. New theories continue to emerge still today such as (Yarman, 2007b, Yavuzoğlu, 2008). Since each tuning theory needs to also specify how pitches are represented, each proposal is naturally accompanied by a new notation system. Designing a Turkish makam music tuning and notation had been a controversial issue especially for the last two centuries due to the complexity of microtonal practice in the oral tradition of Turkey ${ }^{8}$. In addition, the Arel-Ezgi-Uzdilek (AEU) (Arel, 1968, Ezgi 1933) system tuning theory and notation ${ }^{9}$ determined the established notation practice, with its scores being used in music education inside and outside the conservatories. Its insufficiency to reflect music practice was documented ${ }^{10}$ and is wellknown to the musicians, but it nevertheless represents an established system that improved notations would have to challenge.

The AEU tuning theory is based on Pythagorean pitch ratios and divides an octave into 24 not equaltempered notes. Figure 1 shows the accidentals used and the 24 pitches with respect to the pitches of the 12-TET (tone equal tempered) system. While the AEU system specifies Pythagorean pitch ratios such as $3 / 2,9 / 8,4 / 3$, etc. in the basic formulation of the tuning, for simplicity of defining intervals for notation, it uses a basic unit of Holderian-Mercator comma (Hc, obtained by equal division of an octave in 53 equal steps). In other words, intervals found by Pythagorean ratios are quantized to integer multiples of $\mathrm{Hc}$ for notation simplicity. This results in basic minimal interval sizes (between neighboring notes of a scale) of $1,4,5,8,9,12 \mathrm{Hc}$. The basic tri/tetra/penta-chords are formulated

\footnotetext{
${ }^{7}$ An overview of tuning theories for Turkish makam music can be found in (Yarman, 2007b and Atalay, 1989). In addition, Ghrab presents a detailed overview of Western studies on tuning of makam/maqam music (Ghrab, 2005) while the focus being more on the "Arabic tuning" but also including discussions on "Turkish tuning". Turkish folk music is also considered to be explainable by makam concepts. Interested readers are referred to the studies on the tuning of bağlama (e.g. Tura, 1988), the main instrument in folk music. A 17 tone (per octave) tuning (a subset of the 24 tone Pythagorean system) is commonly preferred for tuning studies on Turkish folk music.

${ }^{8}$ For a review of historical notations the reader is referred to (Ayangil, 2008, Popescu-Judetz, 1996).

${ }^{9}$ While plenty of musicologists criticize the Arel (or AEU) theory, it is still the most common. Review of the AEU tuning and notation system can be found in many resources such as (Yarman, 2007b, Signell, 2008).

${ }^{10}$ İstanbul Technical University Turkish Music Conservatory organized in 2008, a congress specifically on deficiencies of the AEU theory in explaining the practice. The complete proceedings are published in English and in Turkish (Ay \& Akkal, 2008). Tura (1988) also discusses this issue in detail.
} 
using these intervals (an example is shown in Figure 2) and the scales are shown to be composed of these chords as in Figure 5.

a)

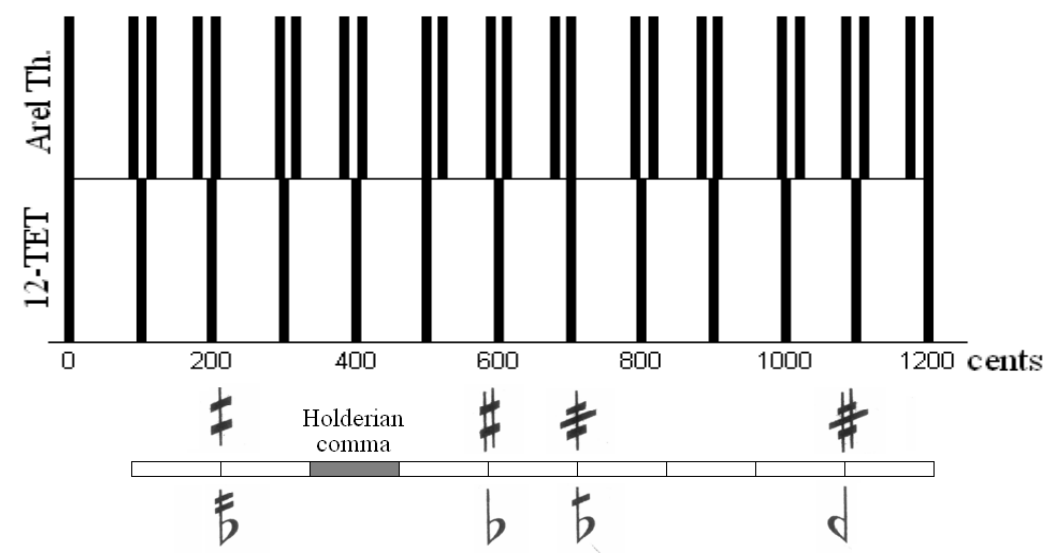

Figure 1. a) 24 pitches of the AEU theory with respect to the 12-TET tones. b) The accidentals (showing interval sizes within a whole tone) used to represent these pitches on the staff.

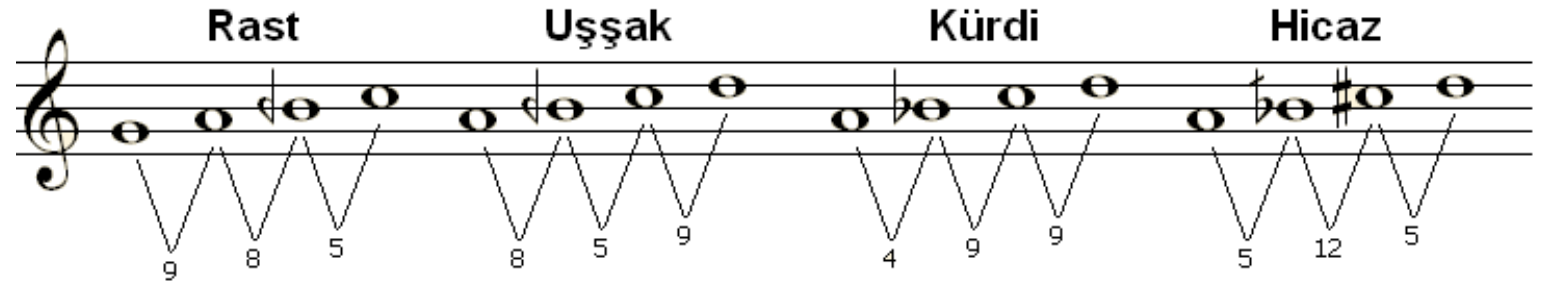

Figure 2. Rast, Uş̧̧ak, Kürdi and Hicaz tetra-chords. Intervals are indicated in Hc. [Figure source: Mus2okur software: http://www.musiki.org]

It is well known today that this tuning theory does not involve some of the very important intervals in practice (as also shown computationally in (Bozkurt, Yarman, Karaosmanoğlu, \& Akkoç, 2009)). The number of intervals and notes necessary to represent the practice is an open topic of research. Furthermore, tunes are notated using the augmented staff notation shown in Figure 2, and those notations are considered to represent the basic structure of a composition, which needs to be respected but also be interpreted by adding notes and embellishments. These differences between performance and notation pose some challenging problems for transcription and style analysis approaches (as discussed in Section 3.3).

An important characteristic of a makam is that some notes in a scale are emphasized more than others. As this emphasis often relates to the note being played often and with long duration in a melody, we can compute a pitch histogram from a melograph representation to study the scale of a makam and its emphasis points. In Figure 3, we provide pitch histogram templates obtained by averaging pitch histograms of multiple files after aligning the karar (as explained in (Bozkurt, 2008)), for three makamlar; Neva, Hüseyni and Muhayyer which use the same scale (shown in Figure 4).

We can observe from the pitch histogram templates that note neva is emphasized in makam Neva (i.e. the frequency of occurrence of this note is higher comparatively), note hüseyni is emphasized in makam Hüseyni and note muhayyer is emphasized in makam Muhayyer. It appears that one of the many ways makamlar obtained their names is by using the name of one of its emphasis note. These notes (neva in makam Neva, hüseyni in makam Hüseyni, muhayyer in makam Muhayyer) are also the 
first emphasized degree in the melodic progression, referred to as "the initial tone" (Öztürk, 2011). Davis (Davis, n.d) cites al-Khula'ii that the concept of a fixed starting degree is a distinguishing feature between the Turkish makam tradition and the Arab traditions.

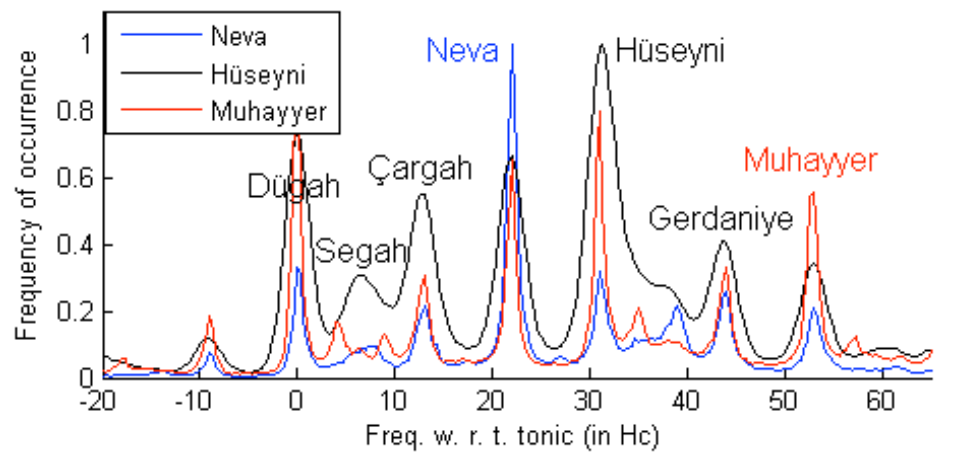

Figure 3. Pitch histogram templates of three makamlar: Neva, Hüseyni and Muhayyer. Names written close to the peaks correspond to note (perde) names. dügah (A), segah (Bd), çargah (C), neva (D), hüseyni (E), gerdaniye (G), muhayyer (A).

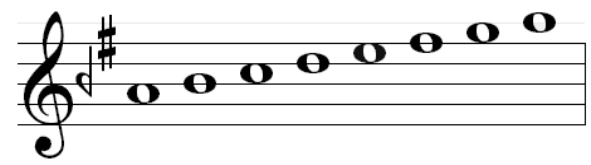

Figure 4. Scale of the three makamlar: Neva, Hüseyni and Muhayyer. Note (perde) names in ascending order: dügah (A), segah (Bd), çargah (C), neva (D), hüseyni (E), eviç (F\#), gerdaniye (G), muhayyer (A).

The fact that the scale of a makam is considered to be obtained from stringing together tri/tetra/pentachords leads to the notes at the end points and interconnections of the chords being attributed specific functions and importance: karar and güçlü. In Figure 5, we present two scales for six makamlar (all of which use the same set of notes in the scale). The colored notes are: the karar is in red (first note of the first chord) and the güçlü is colored blue (note at the conjuction of the chords). Makams having the same scale and güçlü (typically refers to the same note as the initial tone) are differentiated based on their seyirs. The main difference between the two scales is the first being composed of a penta-chord continued by a tetra-chord and the second being composed of a tetra-chord continued by a penta-chord. While most of the theory books would specify the first note of the second n-chord (marked as blue) as the dominant, güçlü, the function of a dominant and if it is a Western term introduced recently to indicate an emphasis note is open to discussion.

a)

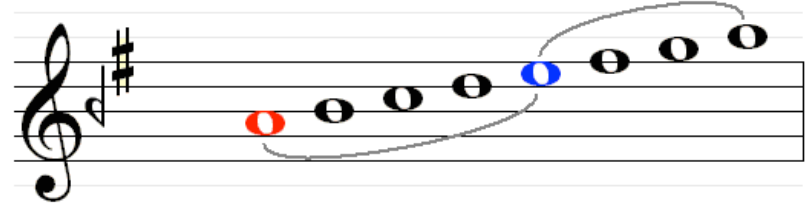

b)

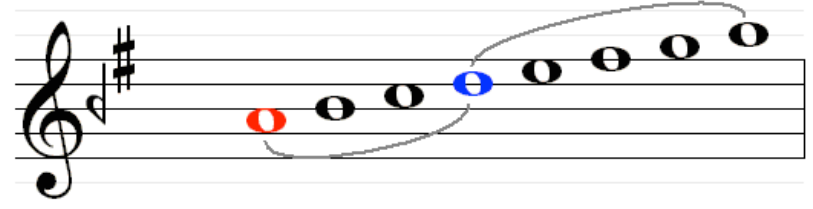

Figure 5. Scales for makamlar according to Arel theory: a) Hüseyni, Muhayyer, Gülizar, b) Neva, Gerdaniye, Tahir. 
It should be stated here again that music practice involves some interpretation of this theory and notation. First type of interpretation is in playing the pitches. The pitch of an indicated note is interpreted using the çeşni information. For example the Si-bemol (of a single Hc) in Figure 5 is played at a lower pitch if it is the second note of a Uş̧̧ak tri-chord than the third note of a Rast tetra-chord (shown in Figure 2). Hence, there is an ambiguity that one note in notation may be interpreted to correspond to two different pitches depending on the musical context. In addition, computational studies (such as Akkoç, 2002, Bozkurt et al, 2009) show that, wider distributions are observed on pitch histograms for certain degrees of the scale (e.g. pitch segah in Figure 3), pointing that interpretation may involve continuum of possibilities instead of fixed discrete frequencies for these specific pitches.

One other important feature of Turkish makam music is the use of several possible concert pitch standards (named as the ahenk system) instead of a single standard (such as A4=440Hz). Almost all notations are written in a single key and in interpretation, ahenk defines an approximate value for the pitch frequency information (or key transposition information). The most commonly used ahenk today is Bolahenk which specifies neva perdesi as about $440 \mathrm{~Hz}$. A table of perde pitches is presented for each ahenk in (Erguner, 2007).

\subsection{Seyir, the melodic progression}

The music theory of Hüseyin Saadettin Arel (Arel, 1968) ${ }^{11}$ presents the makam concept very close to the key concept of Eurogenetic music ${ }^{12}$ and hence tuning and scale are central notions. There is an important deficiency in presenting the seyir, the melodic progression, which is for many other resources the most important feature of Turkish makam music. For example, Öztürk (Öztürk, 2011) considers this scale-centered representation a result of a modernization period to "resemble the West" and states that the traditional Turkish music system is indeed melody-centered. This leads to the fact that music education today starts introducing the basic concepts of the Arel theory (since it's the most common, most of the notations follow its guidelines) and leave a great detail of information to be acquired by performing/practicing the repertoire with a master.

The historical texts (before $20^{\text {th }}$ century, such as that of Abdülbaki Nasır Dede (Abdülbaki Nasır Dede, 1796) and Hızır bin Abdullah (Kitâbü'l Edvâr: 1441) present the makam concept by descriptions of melodic progression rules as road maps (Çelik, 2001, Ayangil, 2001). The rules are often learned by the musicians by studying the repertoire and learning to improvise, rather than reading/memorizing these texts. This reminds of the findings about the cognitive processes involved in improvising in a specific musical context (Berkovitz, 2010), and it motivates to interpret the learning of seyir as a similar process of memorization and conceptualization.

An example of road-map like description is the seyir of makam Rast as explained in (Aydemir, 2010): "The melodic progression begins with the Rast flavor on rast $(\mathrm{G})$ due to the makam's ascending character. Following the half cadence played on the dominant neva (D), suspended cadences are played with the Segah flavor on segah and the Dügah flavor ${ }^{13}$ on dügah (A). The extended section is presented and the final cadence is played with the Rast with Acem (F) flavor ${ }^{14}$ on the tonic rast $(\mathrm{G})$ ".

\footnotetext{
${ }^{11}$ Signell's book (Signell, 2008) presents most of the crucial parts of this theory in a compact form.

${ }^{12}$ We use this term because we want to avoid the misleading dichotomy of Western and non-Western music.

${ }^{13}$ Should be Uşşak flavor. Unfortunately the eager effort of the renowned master Murat Aydemir is overshadowed by occasional errors in the representation.

${ }^{14}$ Should be Rast flavor with acem pitch. This error is possibly due to a translation error.
} 
There are typically three types/classes of progressions stated almost in all theory books: ascending, ascending-descending (or alternatively "seyir in the mid-register") and descending, all of them following the structural organization into zemin-meyan-karar as described in Section 2.1. For an observation on actual data, we can refer to melographs of improvisations. In the examples below (Figure 6), we present an example for each type of progression. In theory, makam Uşşak is considered to have an ascending seyir, makam Hüseyni, ascending - descending and makam Muhayyer descending. For each example, straight lines are indicated by the authors to facilitate the observation. We observed similar shapes in several examples of these makamlar, which indicates that the types of progressions are reflected in the long-term pitch structure observed in the melograph.

a)

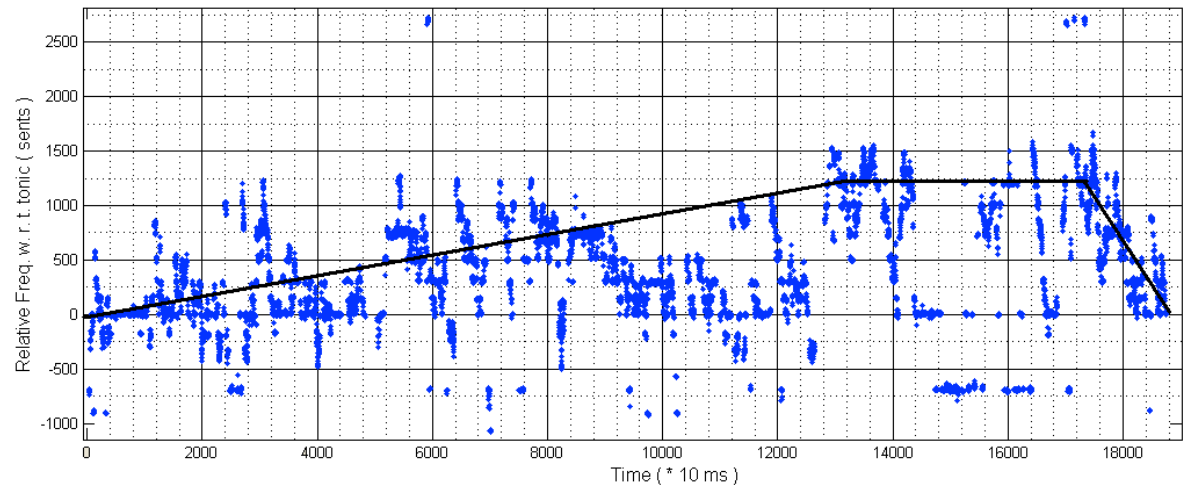

b)

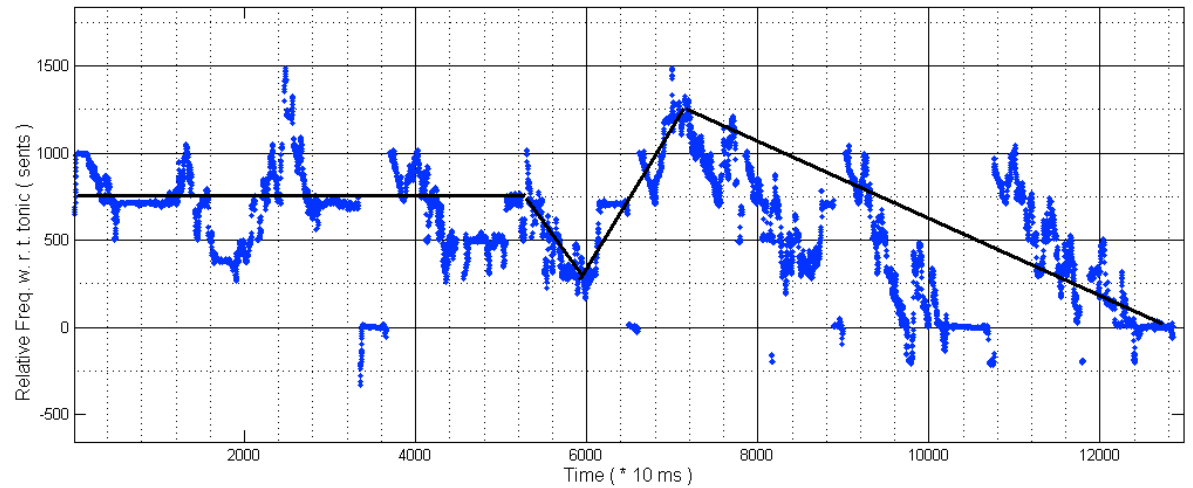

c)

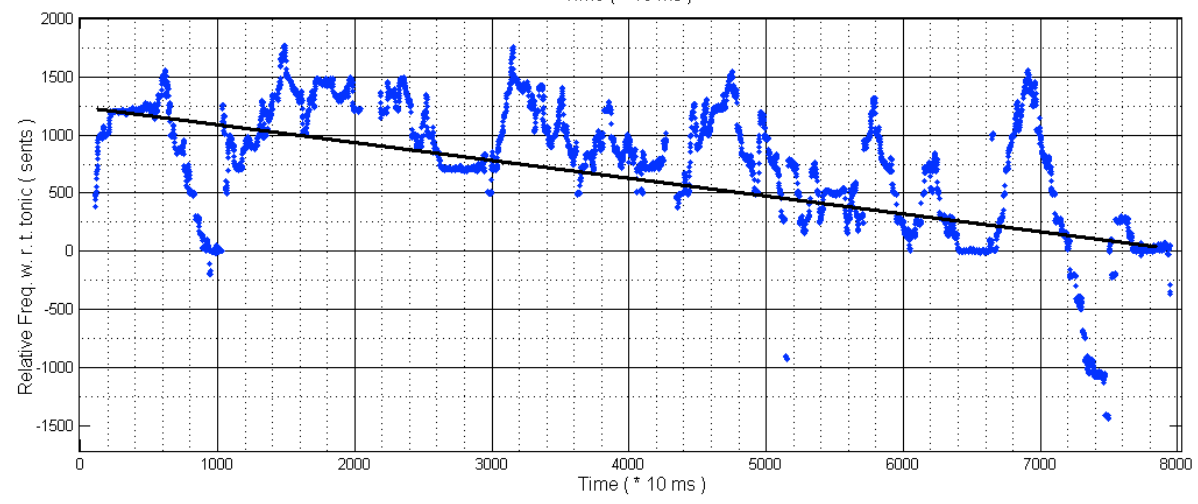

Figure 6. Melographs of taksims in three makamlar: a) Uş̧̧ak (taksim of Yorgo Bacanos), b) Hüseyni (taksim of Fahrettin Çimenli), c) Muhayyer (taksim of İhsan Özgen).

As observed on the graphs, the categorical seyir information specifies the long-term characteristics of the melodic progression and the main differences are observed in the introduction part (as also demonstrated in (Bayraktarkatal and Öztürk, 2012)). A recent study of repertory of Turkish music 
(Karaosmanoğlu, 2012) has shown that the melodic range of a 1700 piece set is about 2.5 octaves at most.

We rarely find references to taxonomies of melodic motives in Turkish makam music theory books. One example is (Signell, 2008), who separates between i) stereotyped motive: the smallest motivic unit to imply makam, ii) cliché: typical phrases and iii) originally invented phrases. Other classifications can be found in (Stubbs, 1994, pp. 221).

While Eurogenetic music is one type of music that has elaborated complex polyphonic concepts throughout its history, melodies in Turkish music are usually referred to as heterophonic. Heterophony refers to the simultaneous variation of a single melody by several instruments or voices, in the context of makam music in most cases in different octaves, as for example in the interplay of ney and tanbur.

\subsection{Usul}

The rhythmic counterpart to the melodic concept of the makam is the usul. An usul is a rhythmic pattern of a certain length that contains a sequence of strokes with varying accents. An example of an usul is given in Figure 7, using note values that imply the durations between the strokes. This or similar forms to notate usul are reported to be used since the 19th century in Turkish music (Marcus, 2001). Strokes on the upper line are executed using the right hand, while those on the lower line are executed using the left hand. These stroke patterns are memorized by musicians using the syllable notation that is shown in Figure 7. The syllable "düm" is usually related to a stronger accent; however, no generally valid way to differentiate the strength of the accents exists.

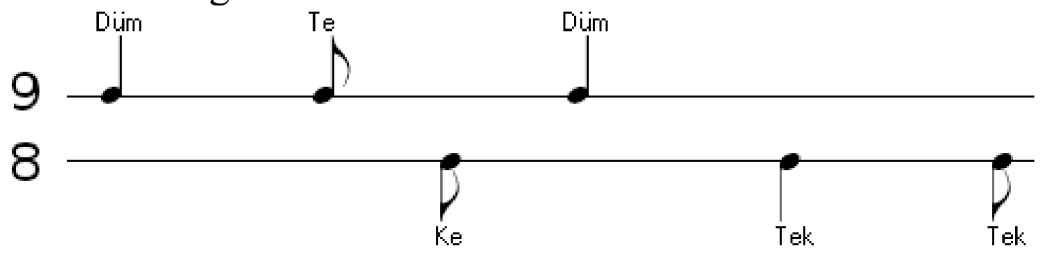

Figure 7. Rhythmic pattern of the usul aksak

The aksak usul shown in Figure 7 has a length of nine, which results from summing up the notated durations, assuming long notes to be of length 2, and short notes to be of length 1 . As Turkish makam music usually uses a Western staff notation, this usul is notated with a $9 / 8$ time signature.

While an usul can be encountered in a wide range of tempi, certain tempo classes are denoted by the denominator of the time signature, which is referred to as mertebe in Turkish language. Using the example of aksak, its slow version is called as ăglr aksak, and shown as a 9/4. Feldman (Feldman, 1996, pp.326) explains that the existence of these slow versions seems to be related to the decrease in performance tempo towards the end of the 17th century in Turkish makam music. In addition, this decrease coincided with an increase in note-density, and basic usul patterns like the one shown in Figure 7 were filled up with additional strokes, resulting in the so-called velveleli-patterns, see Figure 8.

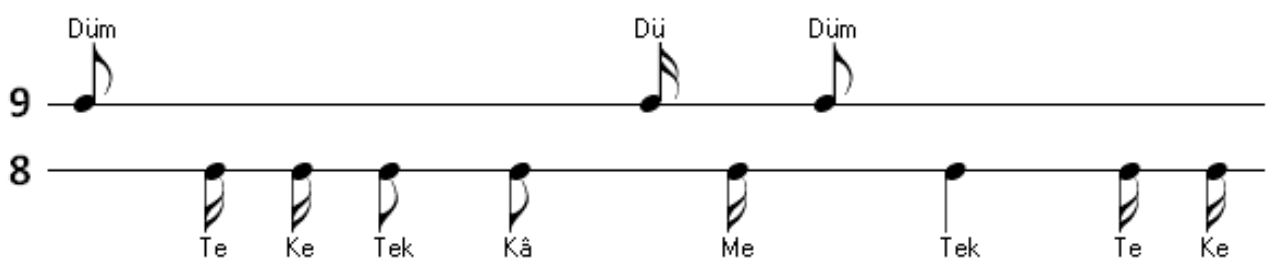

Figure 8. Velveleli pattern of the usul aksak. 
The length of usul ranges from 2 up to 120, where the longer usul are often considered as compound usul, i.e. usul that are obtained by combining several shorter usul. Specific compositional forms make use of either long or short usul. For instance, the popular şarkı form makes use of shorter usul, while the zencir beste often uses longer usul, differences that can be verified on existing music collections (e.g. Karaosmanoğlu, 2012).

When asking the question if an usul can be considered as a musical meter, we have to shortly clarify some notions. If we define a meter as organized pulsation functioning as a framework for rhythmic design (Kolinski, 1973), we are inclined to support the interpretation of usul as musical meter. However, the presence of asymmetries in most usul would render them being interpreted as additive meters, which seems to be an overly complex interpretation in many cases. We suggest to follow Marcus (Marcus, 2001) in referring to usul as rhythmic modes. This places them somewhere in the middle of the continuum between a meter as a mental framework and a rhythm as organized duration on the surface of musical sound (Kolinski, 1973). It is interesting to point out that the makam, as a melodic mode, equally falls somewhere on the continuum which is spanned between a scale and a tune (Powers \& Wiering, n.d., Davis, n. d.).

These rhythmic modes form the basic timeline that is used for the percussive accompaniment in performance. As explained in (Marcus, 2001), the percussive accompaniment usually would not alter strong accents (düm), but rather the weak accents in the usul, which can be embellished by applying additional strokes. Pieces that are not following a rhythmic mode belong usually to an improvised form, such as the taksim. All non-improvised forms follow an usul ${ }^{15}$, which is expressed by the rhythm of the melody emphasizing time instances also emphasized by the usul. It has been object of intensive discussion in how far usul and poetic meter are related with each other. While evidence is there to support this relation (Bektaş, 2005, Tanrıkorur, 2003), Arel had rejected this relation to a wide extent (Arel, 1951).

\section{Computational analysis of Turkish makam music}

\subsection{Tuning analysis}

One of the early works on analysis of intonation (temporal dynamics of pitch) of makam/maqam music (the liturgical music of Christian Arabs in Israel) is that of Dahlia Carmi-Cohen (Cohen, 1964, Cohen, 1969). Using a mechanical device for melody transcription, Cohen derives "tonal skeleton"s from pitch distributions as "logical frameworks in the "chaos" of intonation" and compares them to Chrysanthos theory (Chrysanthos, 1832). Cohen concludes that intonation patterns do not strictly relate to neither Western well-tempered nor Arabic quarter tone system.

Until 2000s, due to the difficulty in accessing means of measurement, studies on scale pitches for Turkish makam music had been mainly limited to reviewing existing tuning theories in literature (Atalay, 1989, Can, 1993, Ersöz, 1994). There have been efforts to study tuning by actually adjusting tuning of a digital instrument during playback of a recording by a master musician by ear and studying the resulting intervals (Kaçar, 2002). Later on, we come across computational studies (Akkoç, 2002, Zeren, 2003) ${ }^{16}$ using pitch histograms of recordings. In those studies, a limited number of examples

\footnotetext{
${ }^{15}$ Rhythmic elements may also be used in improvisational forms (Ayangil, 1998) but not in a fixed-specified way.

${ }^{16}$ In fact, the automatic pitch estimation tools have been available long before Akkoç (2002) especially in the domain of speech processing. One of the most comprehensive reviews on pitch estimation (of monophonic audio recordings) is the dedicated book of Hess (1983).
} 
from well-known musicians (for example only two recordings (Uşşak taksim by Niyazi Sayın and Uşşak taksim by İhsan Özgen) in (Akkoç, 2002)) were analyzed by manually labeling peaks on the pitch histogram of each recording. These studies were criticized by musicians and musicologists for the amount of data used and generalization from this limited data.

In (Bozkurt, 2008) we have introduced a method to process large collections of monophonic recordings by automatically detecting the tonic of each recording, matching pitch histogram of each recording with others and obtaining overall pitch histograms. In that work, automatic tonic detection is achieved by shifting the pitch histogram of a recording in small steps (of $1 / 3 \mathrm{Hc}$ ) over a histogram template (that is either constructed/synthesized from tuning theory or computed (automatically learned) from a collection of recordings, for a specific makam). The shift related to the highest correlation between the histograms is identified, and then the recording's pitch histogram peak that matches the tonic peak of the histogram template is determined. For pitch estimation, the implementation of the YIN algorithm (de Cheveigne \& Kawahara, 2002) by its own authors is used in works of Bozkurt and Gedik on Turkish makam music (together with some post-processing filters to correct noisy estimates and octave errors typical for many pitch estimators explained in (Bozkurt, 2008)). YIN is a popular, autocorrelation based estimator for pitch analysis of monophonic recordings. This limits the data sets to be studied to single instrument recordings. Recently, with the availability of improved multiple pitch estimation (such as (Salamon \& Gomez, 2012)), the content of the data sets can be enlarged to also include multi-instrumental ensemble recordings. To our information, no study has followed such a path yet.

For pitch analysis of multi-instrumental recordings, heterophony is an important obstacle. This leads to a difficulty in multiple-f0 (fundamental frequency) estimation since harmonics in the signals from different instruments appear to be very close in various time instances and deviate in others. Even if this difficult problem is solved, it is an open topic how to deduce a single (main) melodic line from two or more f0 contours.

Using the approach in (Bozkurt, 2008), a comprehensive comparative study of tuning theories and pitch measurements was carried out (Bozkurt et al 2009). This study clearly presents the deficiencies of the AEU system and also provides a means to compare several newly proposed theories. A similar work has been carried out by Özek (Özek, 2011) on recordings of living masters’ solo improvisations. Özek has asked musicians to perform improvisations using each specific çeşni and then studied the pitch distributions (using the tools presented in (Bozkurt, 2011), the Makam Toolbox, a software dedicated to pitch analysis for Turkish makam music) for all çeşniler (plural of çeşni). His findings are consistent with the findings in (Bozkurt et al, 2009). In (Tan, 2011), Tan, also used the Makam Toolbox (Bozkurt, 2011) to study tuning of historical neys (from various museums). His work relates tuning analysis results with locations and dimensions of holes on different neys and show that instrument making practices have evolved throughout time.

The studies mentioned represent computational approaches that compare tone frequencies specified in various tuning theories with the practice on a statistical basis. However, the goal of understanding the tuning as encountered in musical practice is far from being met. We discuss future directions in this domain in Section 4. 


\subsection{Melodic analysis}

A review of existing musicology literature shows that "melodic analysis" of Turkish makam music mainly refers to specifying/listing çeşniler used and the notes emphasized in melodic segments (e.g. (K1lınçarslan, 2006, Eroy, 2010, Gönül, 2010)). Such information is important for disambiguation of pitches. In addition, the progression of çeşniler provide an understanding of how context changes in the general flow of musical ideas and possibly how çeşniler are used in relation to the seyir of a composition.

In Figure 9, melodic analysis as performed by a makam theory teacher from Istanbul Technical University Turkish music conservatory is shown. Each çeşni is tagged with the lowest note of the main chord used (Neva, Buselik, Dügah, etc.) and the name of the çeşni (Buselik, Nişabur, Hicaz, etc.) For example, in the first segmented phrase (labeled as Buselik in Neva), the resolution is on note neva (D), the chord, used to create the melodic phrase, composed of the notes neva (D), hüseyni (E) and acem (F) is the Buselik tri-chord ${ }^{17}$ and nim hicaz $(\mathrm{C} \#)$ note functions as a leading tone for this chord.

Usul: Ağırçenber (24/2) $\circ=18.75 \Rightarrow 10 \mathrm{Dk} 14 \mathrm{Sn}$

\section{Düșmesin Miskin Gönüller Hicaz-Hümâyûn Beste}

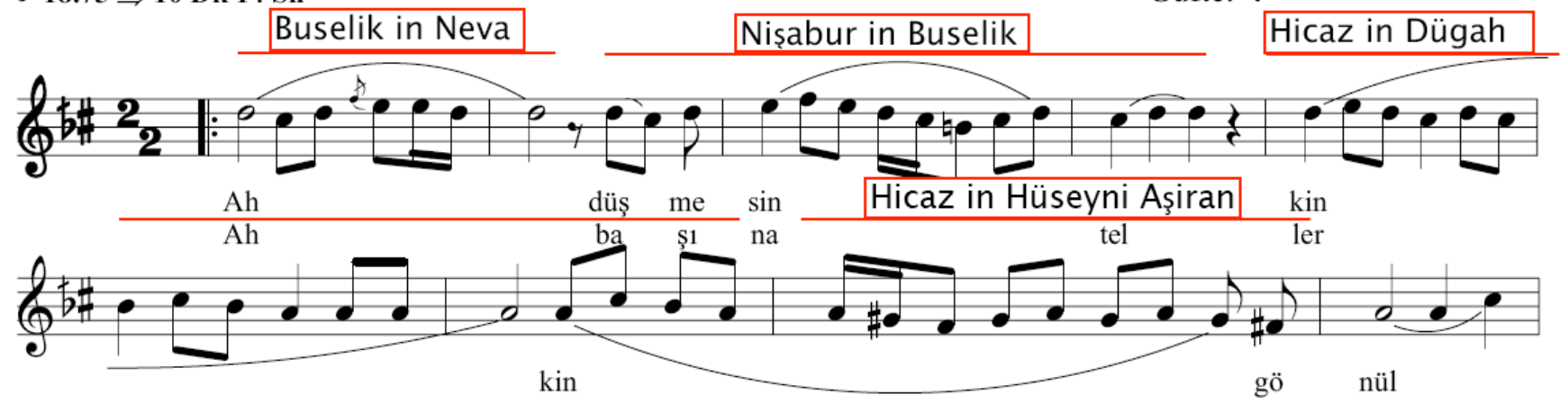

Beste: Zaharya (1680? - 1750?)

Güfte: ? 
Due to the difficulties involved in analysis from audio data, all of the few existing computational melodic analysis studies have been carried on symbolic data. Unfortunately, results of many studies are questionable due to the problems inherent in the symbolic representations/notations as discussed in the previous section. In addition, microtonal notation editor software ${ }^{18}$ was not available until very recently. There have been important technical difficulties in building large machine readable symbolic databases even in the most common Arel notation. In today's music circles, scores of scanned printed images (in Arel notation) are most commonly used. Recently, big archives containing such scanned images have been launched ${ }^{19}$. Part of our work ${ }^{20}$ is dedicated to building machine readable symbolic databases to facilitate such research as explained in Section 4.

Very recently, as more and more musicians are familiar with the use of computer software, the number of scores written using commercial software such as Finale or Sibelius has increased rapidly. Most of the computational studies carried out on symbolic data makes use of such scores exported in the XML format, unfortunately providing very little information about how accidentals have been processed (if discarded or not). It appears to be a common practice to omit Turkish makam music specific accidentals and perform analysis on the resulting data quantized to12TET (i.e. the well-tempered 12 tone tuning, e.g. (Gedik, Işıkhan, Alpkoçak \& Özer, 2005)).

Sümbüllü and Albuz (2011) use such XML data and SQL, SPSS, Excel to gather statistical information. 60 pieces were analyzed for computing pitch occurrences and length, overall pitch range, interval use and rhythmic structure using the SQL database query language. Correlation between histograms for different makamlar has been explored. Their methodology is very similar to a simple pitch class histogram based makam classification via correlation, hence carries very limited information in the context of melodic analysis.

Basic n-gram analysis or Markov chains to find typical phrases of a makam was considered in a group of papers (Yener, 2004, Yener, S., Aksu, C., 2004). These works mainly pick most frequently used ngrams and claim these are the typical phrases. Duration information of notes is either not taken into account or the method of processing is not explained with enough detail. As we have discussed previously, makamlar share a large amount of common phrases and to what level a common phrase is discriminative is open to discussion.

Melodic pattern extraction studies carried out for Eurogenetic music is often based on a representation that combines melodic and rhythmic dimensions (Conklin, 2001, Lartillot and Ayari, 2006, Conklin, 2010) Pattern discovery on such representations leads to capturing rhythmic patterns, melodic patterns and combinational patterns. As stated in the previous paragraph, for melodic analysis of Turkish makam music, such an automatic analysis will become informative when the detected patterns are related to makam music specific concepts. In that sense, the work of Lartillot and Ayari (Lartillot and Ayari, 2009, Lartillot and Ayari, 2011) is among the first studies to consider the link between such concepts and melodic segments (in the context of Tunisian music). They show that makam specific information such as specific emphasis notes can be used to improve automatic melodic segmentation as this apparently resembles how listeners "perform" segmentation.

Automatic modeling/predicting melodies has been considered in (Şentürk, 2011) where VariableLength Markov Models (VLMMs) were utilized. This study appears as the first application of

\footnotetext{
${ }^{18}$ Such as Mus2: http://www.mus2.com.tr/

${ }^{19}$ Such as http://notaarsivleri.com/

${ }^{20}$ The CompMusic project: http://compmusic.upf.edu/
} 
computational modeling in Turkish folk music. However, apart from representing the pitch scale by 17 notes in an octave, no makam music specific information is included in the system design. In addition, the musical relevance of the results is not discussed. Şentürk used multiple viewpoints, where each event in a musical sequence is represented by parallel descriptors such as durations and note values. Tests are performed on a database of the uzun hava form, a non-metered structured improvisation form in Turkish folk music. Their conclusion is that the melodies are highly predictable.

To our knowledge, automatic computational analysis of long-time melodic progression is not targeted in any study in literature. While Şentürk (2011) uses VLMMs and also models the complete piece, the resolution (of one note at a time) is too high for observing long-time tendencies common to different pieces or recordings in the same makam. Hence, while sequences may be very long, due to the resolution being suited to short-time analysis, we consider (Şentürk, 2011) among short-time analysis studies. Computational studies on melodic progression mentioned above are rather limited to consider the short-time aspect of seyir. Computationally studying/modeling of a down-sampled or simplified/summarized version of the pitch contour is one alternative to capture the long-term characteristics of seyir as we demonstrate in Section 4.

\subsection{Automatic transcription}

Since a complete automatic transcription system should ideally involve automatic algorithms to process the rhythm, intonation, structure and timbre (instrumentation) features of a recording, design of such a system is one of the biggest challenges of MIR today.

Due to the limited advances in the above discussed analysis domains for Turkish makam music, the few studies on automatic transcription consider simplified and limited context: transcription of monophonic recordings of instruments for which f0 (fundamental frequency) estimation is comparatively easier (Gedik, 2012, Bozkurt, Gedik \& Karaosmanoğlu, 2011 ${ }^{21}$ ). It is interesting to note that automatic transcription studies for other maqam music traditions share the same limitations (AlGhawanmeh, Jafar, Al-Taee, \& Muhsin, 2011).

The design of an automatic transcription system for Turkish makam music involves many culturespecific challenges. Since the accidentals on the notation and tuning are defined by the makam of the recording, one of the first steps for analysis is automatic makam detection. This topic is addressed in the next section.

The pitch quantization step involves ornamentation detection and classification, as one of the main challenges, since makam music practice involves frequent use of ornamentations. (Gedik, 2012) presents heuristic processing for a few types of ornamentations for a specific instrument and hence its applicability is very limited. There is clearly a lack of broader studies for processing ornamentations.

Another problem in pitch quantization is the mapping of the steady-state portions of the estimated f0 sequences to pitch classes, the notes. As mentioned earlier, the AEU theory specifies 24 notes in an octave, and both the number of notes and the corresponding f0 values poorly represent the practice. Can shows that four of the theoretical pitches are not used at all in practice (Can, 2002). Therefore, the common approach in these few automatic transcription studies is the use of a fine equal tempered

\footnotetext{
${ }^{21}$ Implementations of the algorithms described in these studies are partially available in the Makam Toolbox (Bozkurt, 2011).
} 
resolution (such as 53-TET) and do not limit the transcription with pitches of the AEU theory (Gedik, 2012).

(Gedik, 2012) further discusses in detail the difficulties in evaluation. Various versions exist for the notation of a piece and most often, the original notation used by the musicians is not accessible to the researcher. The interpretations may include improvised short passages not available in the original notation. In the automatic transcription literature, it has been reported in many studies that there is no unique ground truth for manual transcription even among well-trained musicians (Cemgil, 2004). Similar evidence was presented in musicology some decades ago, where a group of subjects transcribed with generally more concurrence than divergence, however agreeing more in terms of pitch than in duration (List, 1974). For these reasons, for evaluation, Gedik prefers to gather a set of transcriptions including the automatic transcription and a few manual transcriptions and provide cross-comparison of the all set. He claims that the goal of automatic transcription can be limited to achieve the level of a manual transcription in matching other manual transcriptions.

The only analysis in the temporal dimension in (Gedik, 2012) is the use of duration histograms (as in (Duggan, O'Shea \& Cunningham, 2008)) to define the length of an eighth note and performing duration quantization using a sixteenth note duration resolution.

In multi-instrumental settings, one of the main difficulties is to cope with heterophony within Turkish makam music. We could not find any work tackling this problem in literature.

\subsection{Automatic makam recognition}

Automatic makam recognition studies may be classified with respect to the type of data used; audio or symbolic.

The task of automatic makam recognition from audio data for Turkish makam music has been considered in (Gedik \& Bozkurt, 2010, Ioannidis, Gómez, \& Herrera, 2011), the former using pitch histogram template matching and the latter using chroma features (Harmonic Pitch Class Profiles, HPCP, (Gomez, 2006)). Pitch histogram based recognition has been previously used for genre detection in Eurogenetic popular music (Tzanetakis, Ermolinskyi \& Cook, 2003). Both studies use some description of the overall pitch distribution and incorporating seyir related features is considered as future direction. Pitch histogram matching for makam recognition has also been implemented and included into the freely available software $\operatorname{Tarsos}^{22}$ (Six, J., \& Cornelis, 2011). One of the difficulties in pitch histogram based classification is the definition of a proper distance metric (that also is supported by musicological analysis results). Gedik (2013) studies this issue on Turkish makam music data and reports that the parameter based metric, Earth Mover's Distance, performs better than the commonly used bin-by-bin measures for makam classification.

Makam recognition studies on symbolic data (Gedik et al, 2005, Ünal, Bozkurt \& Karaosmanoğlu, 2013) are mainly based on n-gram analysis also used in mode detection for Eurogenetic music (Doraisamy, 2004). (Gedik et al, 2005) used a collection of Turkish makam music MIDI files in the 12TET representation and applied a straight-forward n-gram analysis. Unfortunately, there are serious flaws in both the data (size, type of representation and how it is collected) and the evaluation methods presented. In (Ünal et al, 2013) a much larger data set in various representations is collected. A

\footnotetext{
${ }^{22} \mathrm{http}: / / \operatorname{tarsos} .0110 . \mathrm{be} /$
} 
perplexity based metric is used to calculate similarity and various data representations (12TET, AEU system and interval contour) have been compared for efficiency. The results showed that the microtonal representation improves the recognition accuracy when compared to 12-TET. In addition, the usefulness of some seyir related features are tested in a hierarchical framework. It has been shown that discriminative features for makamlar using the same scale but differ with seyirs (such as makamlar Hüseyni and Muhayyer) can be computed from the first few melodic phrases of the piece. The overall efficiency for 13 makamlar using the microtonal representation was reported to be $90.9 \%$ (F-measure) in (Ünal et al, 2013).

Makam/maqam classification has also been studied for other related traditions; Dastgah and maqam recognition for Persian music (Darabi, Azimi, \& Nojumi, 2006, Abdoli, 2011) mainly by using estimated scale intervals information to match with the theoretical scale intervals. Abdoli uses Fuzzy sets to represent measured scale intervals of recordings and further compares this representation to a theoretical set to automatically detect the dastgah. Abdoli reports that an average F-measure of $83 \%$ is achieved on their data of 210 recordings where classification is performed for 5 dastgah classes. Darabi et al. uses Fourier spectrum information as an acoustic feature to estimate scale intervals. Octave wrapping is performed on the spectrum and using the tonic information (not explained how the tonic is detected), this information is converted to intervals information processing the peaks of the spectrum. Then this information is compared with theoretical intervals of each dastgah.

The automatic modality or key classification/detection/recognition studies carried out for other music traditions (such as Carnatic music, Hindustani music, Eurogenetic music) are also relevant. However, due to space limitations, we will not be able to consider them here. Interested readers are referred to existing studies that provide review of existing literature (e.g. Nagavi \& Bhajantri, 2011, Koduri, Gulati, Rao \& Serra, 2012, Gomez, 2006, Temperley \& Marvin, 2008).

\subsection{Rhythm analysis}

Most computational approaches for the analysis of rhythm attempt to estimate certain aspects from surface rhythm usually focused on Eurogenetic popular music. We can attempt to determine the time instances at which a musical instrument starts playing a note (onset detection, e.g. (Holzapfel, Stylianou, Gedik, \& Bozkurt, 2010)). Regarding the meter of a piece, we can attempt to track the most prominent pulsation in a piece (beat tracking, e.g. (Davies \& Plumbley, 2007)), or we can attempt to track where a larger rhythmic cycle starts, such as the bar or measure in Eurogenetic music (downbeat detection, e.g. (Hockman, Davies \& Fujinaga, 2012)). The recognition of the type of meter is also a task that was approached in the scope of recognition of the time signature (Pikrakis, Antonopoulos, Theodoridis, \& Theodoridis, 2004). Furthermore, rhythmic similarity approaches were proposed that often do not assume any knowledge of the underlying meter (e.g. (Holzapfel, Flexer, \& Widmer, 2011)).

The computational analysis of rhythm related aspects in Turkish music is generally an open field. Most of the above listed tasks, framed in the musical concepts of makam music, make sense when applied to Turkish music. For instance, from an engineering point of view the detection of the start of the rhythmic cycle of an usul is related to the task of downbeat detection. However, it is apparent that the way the beginning of an usul is reflected in the music can be quite different from the way the beginning of a bar is marked in e.g. Eurogenetic popular music. Nevertheless, an adequate downbeat detection for Turkish music can help in the automatic analysis of Turkish music. Possible applications would be a structure-informed media player for learning and practice purposes, or automatic transcription. In a similar fashion, all of the above mentioned approaches make sense when applied to Turkish music. 
However, as our recent experiments document (Srinivasamurthy, Holzapfel \& Serra, 2013), the stateof-the-art approaches, which were in their majority tailored for Eurogenetic music, fail to provide us with results of sufficient accuracy.

To the best of our knowledge, the few pioneering studies of computational analysis of rhythm in Turkish music were attempted throughout the last years, and were initiated by members of the group presenting this paper. Chronologically, in (Holzapfel \& Stylianou, 2009) a collection of MIDI samples of Turkish melodies is classified into its rhythmic classes made up by the usul. Because compositions following a specific usul are interpreted as being rhythmically similar to each other, the approach applies an instance based learner to pair-wise distances computed between rhythmic features obtained from individual songs. Including a Scale Transform (Cohen, 1993) into the feature computation was shown to improve the robustness to tempo differences, but the implication that this leads to applicability to audio recordings could not be verified in (Holzapfel \& Stylianou, 2009) as no usullabelled collection of such recordings was available at that point. In our recent experiments on audio recordings (Srinivasamurthy et al, 2013), we obtained usul recognition results significantly lower than the ones obtained on symbolic data in (Holzapfel \& Stylianou, 2009). This implies that the description of a whole song with one vector that summarizes periodicities related to rhythm achieves a level of discriminative power that is not sufficient to recognize an usul.

In our recent work we were able to obtain a more detailed insight into the way the surface rhythm of a composition and the accents of an usul correlate (Holzapfel \& Bozkurt, 2012). We found that note onset locations are highly correlated with the strokes of an usul, and that long note durations are aligned with highly accented strokes in the usul. Furthermore, we encountered a phenomenon that resembles syncopation in Eurogenetic music in some usul, which indicates that melodies tend to place pauses on strong strokes in the first half of an usul.

An insight into the characteristics of non-metered Turkish music is provided in a recent contribution (Holzapfel, 2013), where we shed light on the temporal evolution of pulsation in improvisation. Preliminary findings show clear difference between the rhythmic idioms of different players, regarding the strength and continuity of the occurring pulsation in their recordings.

Summing up, we have to acknowledge that little has been done on computational analysis of rhythmic aspects in Turkish music, and that our contributions represent only first steps into a wide field. It is worth to note that the few computational studies in other makam traditions focused on melodic aspects, and the analysis of rhythm, to the best of our knowledge, was not treated in any such study on computational methods.

\subsection{Studies on timbre and instrumentation}

In literature we find computational timbre and instrumentation studies for Turkish makam music mainly in three categories: automatic instrument detection studies within the context of MIR (music information retrieval), studies for acoustical properties of specific instruments (mainly involving spectral analysis of stationary parts of isolated sound signals), and instrument modeling for synthesis purposes.

Works on automatic classification of Turkish music instruments target straight-forward application of machine learning methods on spectral features. (Dura, 2001) used neural networks to develop an automatic classification system for Turkish music instruments: ney, kanun, kemençe, tanbur. This work 
appears as a preliminary work; the acoustic feature used for classification is simply the frequency and amplitude information of the spectral peak for each signal frame and the database used for both learning and testing is a set of 12 single note recordings for each instrument. Özbek and Savac1 (2009) conducted a standard automatic recognition study where MFCC features are used in a Support Vector Machine (SVM) framework. The instruments are kanun, keman, kemençe, clarinet, ney, tanbur and oud and high success rates are reported for recognition. Holzapfel applied statistical modeling to a set of features derived from a Non-negative matrix factorization (NMF), in order to discriminate between various instrumentations of ensembles playing Turkish and Greek music examples (Holzapfel, 2010). These studies provide very little information for understanding the timbre or acoustics of Turkish music instruments. Their design and testing does not include any culture specific information or analysis.

(Erkut et al, 1999, Erkut \& Valiki, 2000) undertook the first and, until now, the most serious study of acoustics of a Turkish music instrument. They show that the tanbur has several acoustic properties that are not common in Western plucked string instruments. They report that the tanbur strings exhibit pronounced nonlinear tension modulation effects, i.e. variation of the fundamental frequency and coupling of the harmonic components. Gökbudak (2011) attempts to study acoustics of kanun and tanbur but this thesis study is only limited to measuring and reporting harmonic amplitudes and frequencies, formant frequencies, sound pressure levels.

\subsection{Other topics}

Below we consider several computational studies carried for Turkish makam music that do not fall into the above categories.

In two studies, computation of the fractal dimension of notes sequences in several Turkish makam music pieces are considered (Gündüz \& Gündüz, 2005, Tarikci, 2012). Both studies used symbolic data represented in the Arel notation system.

Tarikci consider fractal dimension as a measure of complexity/simplicity in melodies. Tarikci studies melodies classified according to the makam. His results point that some makamlar exhibit more irregular patterns than others and "Turkish art music songs show a fractal behavior". On the other hand, he states that all songs in the test database had similar fractal properties (Tarikci, 2012, pp. 80). Unfortunately, the link between measurement results and the musicological concepts is not discussed in detail in this study.

In (Gündüz \& Gündüz, 2005), the authors also propose various graphical representations for melodies including a radial distribution of notes, animal diagrams, etc. They demonstrate that such representations help visual detection of similarities in sections of a piece hence can be used in automatic structural analysis. They further study methods to mathematically model structures in these graph representations.

Özaslan, Serra and Arcos (2012) performed an analysis of the fundamental frequency contours to estimate vibrato rate change and pitch bump in 327 manually segmented embellishments, vibrato and kaydırma from 8 ney recordings. Şentürk, Holzapfel and Serra (2012) studied automatic linking of sections in symbolic notations with the sections in corresponding audio recordings by matching synthetic pitch contours obtained from notation with the estimated pitch contour from audio. 


\section{Potentials and Future challenges}

In the first sections, we discussed the basic concepts of Turkish makam music briefly and reviewed the computational analysis literature. Our goal in this section is to consider open topics, future directions and available resources. We start with announcing our data (which will be open in the future for research-only purposes) that may be of interest to readers aiming at studying makam music.

\subsection{Collecting data}

Most of the computational studies we have considered suffered from unavailability of machine readable, tagged/segmented/classified data. Until now, the financial support, hence the amount of research oriented data collecting efforts for traditional music has been very low. With the support provided by some recent projects ${ }^{23}$, we had the opportunity to bring together various collections of data. Here we provide some information about this data.

A collection of audio data ( 4500 files) in the format of mp3 files (with a minimum of $160 \mathrm{kbps}$ coding rate) has been gathered from commercial releases. The metadata available in the album covers (such as track names, composer, musicians and their instruments) have been both encoded as mp3 tags and also entered into the internet-based platform MusicBrainz ${ }^{24}$. For each track, additional tags regarding makam, usul and form information have been stored (on MusicBrainz), partly based on information from scores if information was not given in the liner notes. The meta-data on MusicBrainz is accessible to the public via internet. The audio file collection (which makes part of a larger collection of a larger data set (Sordo et al, 2012)) is partly available for research purposes upon request from the authors of this paper. In the early phases of these data collection efforts, the fundamental frequency analysis results (i.e. pitch contours) for 25 albums of this collection were previously shared to help tuning research by Bozkurt et al (2008). This data is still available upon request from its authors.

The SymbTr database (Karaosmanoğlu, 2012), consisting of 1700 scores in machine readable format (text files), is opened to public on the CompMusic official site ${ }^{25}$. In addition, scores in pdf document form and MIDI files are included as well. This collection attempts to include corrections of various master musicians, who replaced certain pitches of the AEU theory by alternative pitches defined on a 53 TET division. For 550 of these scores, there exist one or more audio recordings (a total of $850 \mathrm{Mp} 3$ files) as interpretations in the above mentioned large collection of audio files. Hence, a large amount of data for studies that need parallel data (score and audio) is also available. In addition, a score database is currently being manually segmented by experts in terms of melodic phrase boundaries and çeşni information as shown in Figure 9. This data will serve as a basis for automatic melodic boundary and çeşni detection studies. Another recent data collection project was carried by Atalay and Yöre (2011) where the authors produced and shared ${ }^{26} 600$ machine readable notation files containing note names and durations in table form.

\footnotetext{
${ }^{23}$ i) Tübitak 107E024: "Automatic transcription of Turkish Classical music and automatic makam recognition", ii) CompMusic, "Computational models for the discovery of the World's Music", "http://compmusic.upf.edu”, iii)Tübitak 112E162, "Automatic melodic analysis of Turkish makam music".

${ }^{24}$ http://www.musicbrainz.org

${ }^{25} \mathrm{http}: / /$ compmusic.upf.edu/node/140

${ }^{26} \mathrm{http}$ ://www.tsmderlemi.com
} 
The score and audio collection linked to meta-data on MusicBrainz can be easily clustered with respect to form, makam, usul, composer, date of recording/composition, instruments, etc. Therefore, it can serve a large variety of MIR research on Turkish makam music.

We conducted recordings of four basic percussion instruments; kudüm, bendir, def and darbuka, playing 15 most common usuller of makam music in various styles and tempi, by a professional musician from TRT (Turkish Radio Television). These recordings are accessible on http://www.freesound.org/people/barisbozkurt/.

For automatic onset detection studies, a collection of manual onset labels was created in (Holzapfel et al, 2010) for Turkish music samples. This data is available at request from the authors. The dataset contains short monophonic recordings of 11 instruments, among them four Turkish instruments (kemençe, ney, tanbur and oud). For each recording, time-labels for the note onsets are available.

In the scope of our study on rhythm analysis for Turkish and Indian music (Srinivasamurthy et al, 2013), 63 excerpts of one-minute length from şarkı following the usul aksak and düyek were manually annotated with their usul strokes. Therefore, separate files containing the time instances for right and left hand strokes were compiled. This dataset is available as part of the CompMusic collection on request for research purposes.

We hope these collections will compensate to some extent for the current lack of data and support a large variety of computational studies. Building interactive educational tools and music discovery systems (Serra, 2011) are future research and development areas that will potentially benefit from the available data and recent advancements in technology discussed here.

\subsection{Tuning}

As discussed in Section 3.1, tuning analysis based on overall pitch histograms is possibly the most largely studied domain for computational analysis of Turkish makam music. Today, we have sufficient data and results to compare theoretical intervals with intervals that can be computed from overall pitch histograms. However, the following research questions are left unanswered: How many clearly distinguishable notes are preformed (in an octave)? Is this tuning consistent across different schools? How are micro-tunings used/related to personal style and expression? What is the effect of melodic direction to tuning? How to overcome the problems in fundamental frequency detection for heterophonic audio signals?

The overall pitch histograms are especially good for detecting tuning frequencies of emphasized notes. Most of these future directions suggest that new representations (based on a finer time resolution than the time of the complete recording) are needed to take further steps in tuning analysis.

Another potentially useful direction in tuning research is perceptual studies. We don't have access to any study that tests tuning theories perceptually in the context of Turkish makam music. As a matter of fact, in many research domains (such as automatic makam detection), we lack perceptual data.

A study of instruments and their tuning shows that many different strategies have been used for tuning and fretting. For fretted string instruments such as tanbur, fretting templates are used by instrument makers and no standard is available (Gedik, Bozkurt \& Çırak, 2009). Most of the kanun (a zither-like instrument) players today, tune their 12 string triplets (in an octave) to 12-TET and further use 
mandals $^{27}$ ( 5 to 9 of them are available for each string group) for microtonal adjustments. For tuning of ney, it is common to use ratios (of instrument length) to open holes and further make adjustments (altering the radius of holes or length of the instrument) by ear. Sethares has shown that timbre of an instrument plays an important role in the tuning system (Sethares, 2005). The link between instrument timbre and tuning is an unexplored domain for Turkish makam music.

\subsection{Seyir}

The concept of seyir has short-time and long-time facets. All computational analysis efforts in literature have concentrated on the short-time aspect (using n-grams or Markov chains) with a very critical lack; without considering melodic boundaries or emphasis notes of the phrases. In melodic analysis of Turkish makam music (which also corresponds to short-time seyir analysis), the functional category of each melodic phrase is defined as a function of the emphasis/resolution note and the intervals with respect to that note, referring to a specific çeşni. Hence, an automatic detection of emphasis notes and çeşniler is a basic challenge we have to tackle for studying short-time seyir aspects. This has not been addressed in any of the existing studies on seyir.

When practices of experts on labeling (on a score) çeşniler are studied (on the data we have gathered, e.g. Figure 9) and content of makam courses in conservatories are considered, we observe that the underlying mechanism is rather straight-forward: determining the melodic boundaries via detecting emphasis notes, then matching the tri/tetra/penta chord (used in the melodic phrase) to a specific çeşni class. Özek uses 14 çeşni classes for his study (Özek, 2012), which is available in the glossary section at the end of this manuscript. Therefore, one of the main challenges in computational approaches is the task of automatic emphasis note and melodic boundary detection. Once this is achieved, automatic çeşni analysis would be comparatively easier.

As we have discussed in Section 2.3, seyir also has a long-term facet. In fact, the most explicit information mentioned about seyir in theory books concerns long-term dimension. Mainly three categories are used: ascending, ascending-descending and descending. No computation study considered a detailed analysis of this long-term characteristic.

As an initial attempt, we present below data related to two makamlar, which are stated to be different only regarding their seyir. We used the large collection of scores contained in our SymTr database. Makamlar Muhayyer and Hüseyni use the same scale (shown in Figure 4) and in theory, makam Muhayyer is sometimes referred to as the descending version of makam Hüseyni.

We down-sampled the melodic contours of pieces from the same makam (so that they have the same length (of 100 points) and plotted these as points in Figure 10 (this approach has been recently introduced in (Bozkurt, 2012)). In this plot, each point refers to an average pitch (of a \%1 (of the total) length segment) that does not necessarily correspond to a pitch of the scale. The solid lines shown in the figures are obtained by averaging all melodic contours.

It is interesting to observe that the average contour follows the structure defined for seyir where this is not always easily observed for individual pitch contours (of pieces). For example for makam Hüseyni, the progression is said to start by emphasizing note hüseyni (pitch no: $336 \mathrm{Hc}$ with respect to $\mathrm{C}_{-1}$ ). While the average contour starts around hüseyni, individual dots are observed to appear distributed in

\footnotetext{
${ }^{27}$ Mandal (trans.: latch/clip) is a small mechanical device on the instrument kanun, used for fine tuning adjustments (of discrete intervals on the level of a few Hc) during actual musical performance.
} 
the 320-350 Hc region. As a matter of fact, there exists data distributed in the 305-350 Hc region throughout the entire duration and there is a challenge involved in extracting long-term seyir information from individual melodic contours. The largest difference between these two progressions (for Muhayyer and Hüseyni makamlar) is observed during the first quarter. Similar observations are made for other very close makam couples that use the same scale but have different seyirs. In our private communication with the masters of Turkish makam music, they found these figures very informative. Average melodic contours are potentially useful for comparison of data clustered into makamlar.
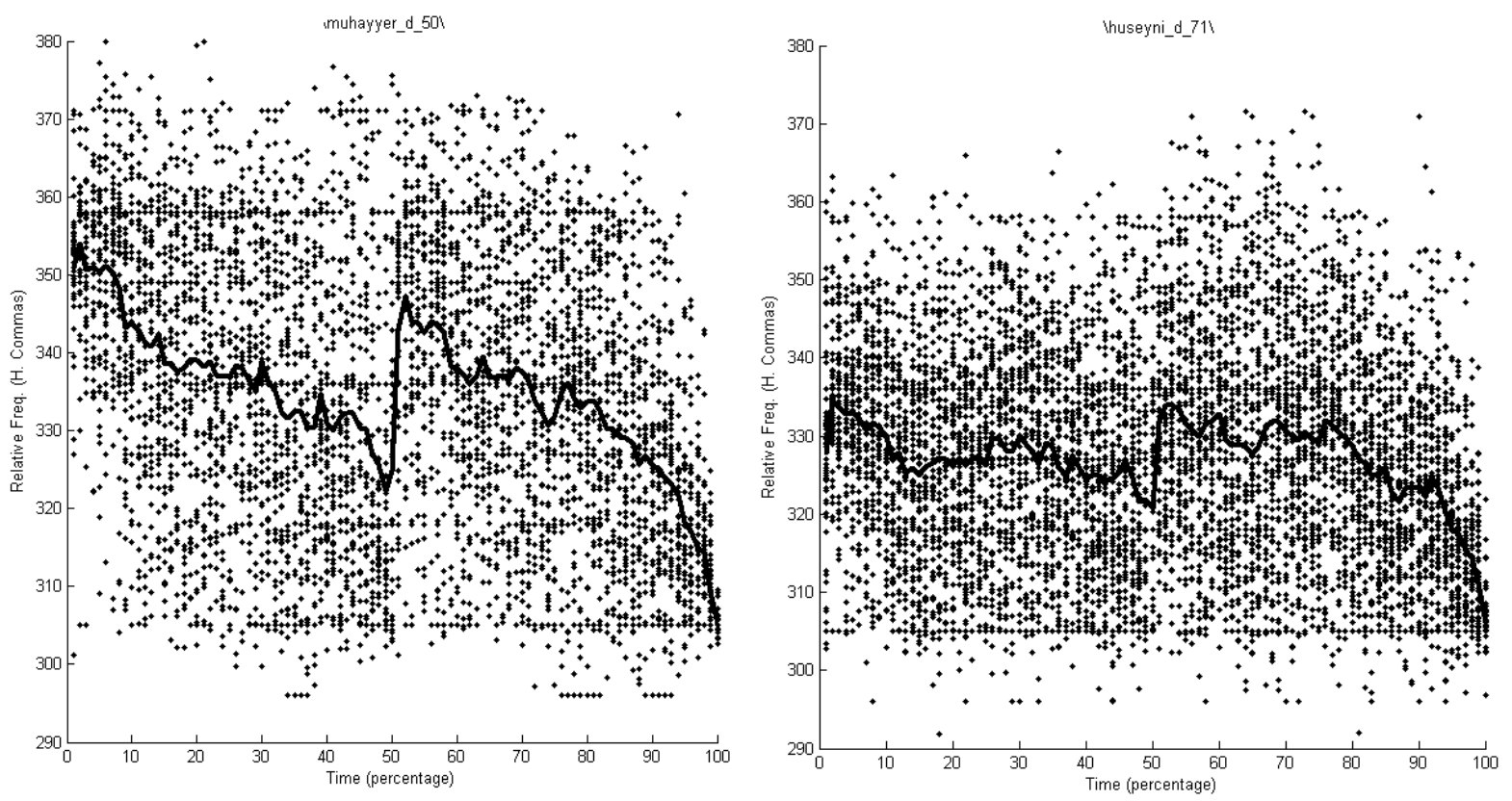

Figure 10. Individual (dots) and average (bold line) melodic contours for makam Muhayyer and Hüseyni (from symbolic data). (Pitches are represented as intervals (in $\mathrm{Hc}$ ) with respect to $\mathrm{C}_{-1}$ )

\subsection{Automatic transcription and score following}

The task of automatic transcription is a challenging one for all types of music. The specific difficulties involved for Turkish (and possibly other) makam music transcription are: heterophony, problems of theory and notation, frequent use of ornamentations, difficulties in onset/beat detection. The problems of automatic transcription of Turkish makam music is discussed in detail in (Gedik, 2012).

Considering the freedom of the musician in interpretation of the piece, achieving a transcription close to the original notation used for performance is a quite challenging problem (Benetos \& Holzapfel, 2013). In the context of Turkish makam music, the performance styles such as melodic and rhythmic variations and ornamentations constitute part of the most important characteristics (Ayangil, 2008, pp. 445). Transcription methods enabling varying levels of detail would be hence favorable.

One of the basic steps of automatic transcription is the automatic tonic detection. While the histogram matching approach presented in (Bozkurt, 2008) is highly effective for monophonic recordings in simple makams, its effectiveness suddenly drops for multi-instrument recordings (especially for those including a high-pitch and a low pitch register instrument) and for some compound makams (where two different scales are used and the tonic is rarely visited). Detecting the final resolution note from the 
pitch contour and combining this information with the histogram matching result is one possible way for improvement.

Another challenging task is to detect/segment specific çeşniler from the f0 contour, which is needed for disambiguation of certain notes. In addition, automatic ornamentation segmentation tools are needed to simplify the f0 contour and also be able to notate these ornamentations. To our information, no study has considered any of these challenges in detail up to now.

As shown in (Srinivasamurthy et al, 2013), there are also specific challenges involved in detection of rhythmic parameters. It appears that automatic transcription of Turkish makam music involves a large variety of challenging problems.

A related research topic is the task of score following: matching segments of a score with segments of a given audio recordings. Applications that use such methods can provide interactive music browsing facilities, e.g. in a computer-based learning environment. It is well known that for Turkish makam music, there is a large room for interpretation and the notation serves to some level as summary of the essential melodic content. This requires an averaging over the melody contours obtained from a performance, and makes great demands on the similarity measure that is applied to compare contours of performance and notation. Furthermore, in performances often some structural elements of a composition are omitted, or not repeated as indicated in the score. This means that an audio-score matching needs to be flexible to such deviations, which was achieved for Eurogenetic music by applying flexible dynamic programming schemes (Fremerey et al, 2010).

\subsection{Rhythm Analysis}

An obvious task for automatic analysis of rhythm in Turkish makam music is, given an audio recording of a performance, to find how the strokes of an usul are aligned with that recording. Then based on such an alignment, properties of the surface rhythm can be examined, i.e. one can address the question how the underlying rhythmic mode (usul) and the rhythmic elaboration in the sound are related to each other. On a more practical level, such an alignment enables to browse music performances in a structural way using intelligent media players, or one can pursue the task of retrieving similar tunes by applying more local comparisons between phrases included into the individual usul-cycles.

A first attempt would be to combine existing approaches to obtain an alignment of usul strokes and recording. This could include applying three-step estimation scheme: first, an automatic beat tracking to track a prominent regular pulse, secondly, estimating the length of an usul cycle with the obtained beats as units, and then, thirdly, selecting the beat instances where an usul cycle starts using a downbeat detection algorithm. As we showed in (Srinivasamurthy et al, 2013), applying a combination of stateof-the-art approaches in such a way has little potential to provide promising results. One of the main reasons for that seems to be the focus of most computational approaches on Eurogenetic styles of music. Rhythm in Turkish music deviates from the assumptions that underlie most software approaches in some very substantial ways. First, we have to deal with the fact that most Turkish makam music uses usul that resemble additive meters. That means that the strokes we search for are not equally spaced, and therefor rhythm in Turkish is not consistent with well-formedness rules that were set up for Eurogenetic music (Lerdahl and Jackendoff, 1983). Furthermore, each single usul is encountered in a large range of different tempi. While this changes the surface structure of the sound significantly, still the piece is considered to be part of the same rhythmic mode. In addition to the tempo ranges of each individual usul, we encounter usul of very different lengths, ranging from 2 to 120, which translate into 
durations of a rhythmic cycle from less than a second to more than a minute. It is apparent that structures of such length are not only affected by rhythmic aspects, but that the melodic structure and its organization into phrases play an important role as well.

Therefore, it appears advisable to pursue a rhythmic analysis of makam music in a more holistic fashion. This should take the mutual dependencies of rhythm and melodic phrasing into account. In addition, pursuing tasks of onset detection, beat tracking, and the estimation of the first stroke of a rhythmic cycle have significant inter-dependencies as well. While this holds for music in many cultures, few steps have been undertaken only in such directions.

Furthermore, we would like to point out that a holistic approach should not restrict itself to an analysis of the sound. For a given composition, we usually are informed about the underlying rhythmic mode, in the same way as we usually are aware of its makam, because both information are widely available in meta-data for all compositions of Turkish makam music. Therefore, an estimation of the length of a rhythmic cycle is not needed in those cases. Adding to that, aligning structural elements notated in a score with a recording could be another source of information to support the usul alignment.

\subsection{Other Research Topics}

In addition to the above-mentioned topics, a large number of research problems could be considered as potential research areas here. One example is automatic structural analysis where repeating sections or similar variations within a piece could be detected to achieve automatic sectioning or form analysis of a recording. Music information retrieval (MIR) domain contains plenty of applications and research problems that can (and has not been) be considered for Turkish makam music: cover detection, automatic music recommendation, melody retrieval, query by humming, etc. We leave these discussions for further studies due to space limitations.

\section{Conclusion}

Computational analysis of traditional music is gaining increasing interest from researchers from various disciplines. The review here is aimed at providing an overview and perspective for future computational studies on Turkish makam music. To provide a musicological background, we have also briefly presented basic concepts of Turkish makam music.

An important aspect of research and development in analysis of Turkish makam music should be the flexibility of the applied methods. Within the frame of Turkish makam music, we emphasized that a combined analysis of rhythmic and melodic aspects should be pursued. Instead of developing highly specialized and overly complex methods, that will serve only the analysis of a specific repertoire, it seems to be advisable to propose methods that are open towards the adaption to different musical styles. Such methods should be conceptualized within frameworks that allow the changes of inputs as well as changes in the way these inputs are interpreted by the system. Our methods will be increasingly applied in order to select and organize the vast music collections that are available to users. Methods that concentrate on particular styles and ignore the musical "other" are likely to lead to an exclusion of large parts of the world's music from the access provided by our future music distribution systems.

\section{Acknowledgments}

This work was funded by the European Research Council under the European Union's Seventh Framework Pro-gramme (FP7/2007-2013)/ERC grant agreement 267583 (CompMusic). 


\section{Glossary}

Karar (Perdesi): Final resolution pitch/note for a makam.

Karar (Etmek): Resolution as cadence perfect. Various translations have been given by Öztürk (Öztürk, 2011) referring to historical resources: "to decide", "making a decision", "to rest", "to come and sit", "to arrive and rest".

Ahenk: Key transposition information (which also specifies the reference tuning frequency).

Güçlï: The note that is mainly emphasized in the interlude which often (but not always) coincides with the first note of the second chord making up the scale.

Çeşni: Descriptive, functional melodic motive using a specific cins (jins, ajnas derived from genos, genre) or sub-division of cins. Some authors (e.g. (Özek, 2011, pp. 6)) consider çeşni as equivalent of cins, or tri/tetra/penta-chords. We think this is misleading since çeşni refers to a function (taste) which uses the chord material. Davis (Davis, n.d.) states that the concept of chords "originated in medieval Arab treatise, but dissappeared between 16th and 20th centuries. They were reintroduced into Turkish music theory by Rauf Yekta and Sadettin Arel in the early 20th century, and to Arab music by Yekta's student, the Syrian Shaykh ali Al-darwish..."

A list of tetra/penta-chords is given together with intervals defined in the AEU theory and measurements from (Bozkurt et al, 2009) in Table 1. In (Bozkurt et al, 2009) scale pitches for the most common 9 makamlar have been studied. For this reason, data for some chords are not available. As explained in (Wright, 1990), the chords have been subject to changes in history, some of them have not been mentioned in treatises for certain periods and are later re-introduced in varied ways. The list below presents chords specified in recently published theory books most of which base on the AEU theory.

\section{Chord}

Çargah tetra/penta-chord

Rast tetra/penta-chord

Uşşak/Hüseyni tetra/penta-chord,

Buselik tetra/penta-chord

Kürdi tetra/penta-chord

Hicaz tetra/penta-chord

Segah tetra/penta-chord

Saba tetra-chord

Müstear penta-chord

Hüzzam penta-chord

Nikriz penta-chord

Pençgah penta-chord

Ferahnak penta-chord

Nişabur tri-chord

* Average of the first 4 intervals computed for Uşşak and Hüseyni makamlar

Table 1. Çeşniler and their theoretical and measured interval sequences. Underlined values indicate pitches where the difference between the theoretical and measured values is greater than $1 \mathrm{Hc}$.

Theoretical Intervals in Hc (AEU) Measured Intervals in Hc (Bozkurt et al, 2009)
994 / 9

$985 / 9$

$859 / 9$

$949 / 9$

$499 / 9$

$5125 / 9$

$598 / 9$

855

9589

59512

95125

9985

5998

94

$\begin{array}{llll}9.17 & 7.47 & 5.26 & 9.12 \\ \underline{6.32} & \underline{6.16} & 9.36 & 9.36 \\ 9.38 & 3.52 & 9.17 & 8.88 \\ \underline{5.26} & \underline{7.45} & 9.19 & 9.20 \\ 4.65 & 12.16 & 4.98 & 9.30 \\ 4.68 & 9.40 & 9.03 & \underline{7.58} \\ 7.61 & 5.18 & 5.91 & \\ 4.99 & 9.18 & \underline{6.28} & \underline{10.52}\end{array}$$$
\underline{6.28} \quad \underline{10.52}
$$ 
Perde: Pitch/note or fret.

Seyir: Melodic progression of a specific makam.

\section{References}

1. Abdoli, S. (2011). Iranian Traditional Music Dastgah Classification. Proceedings of ISMIR, pp. 275-280.

2. Abdülbaki Nasır Dede (2006) Tedkik ü Tahkik [1796], (Ed. Y. Tura), Pan Yayınları, İstanbul.

3. Akkoç, C. (2002). Non-Deterministic Scales Used in Traditional Turkish Music. Journal of New Music Research, 31(4), pp. 285-293.

4. Al-Ghawanmeh, F. M., Jafar, I., Al-Taee, M., \& Muhsin, Z. (2011). Development of Improved Automatic Music Transcription System For The Arabian Flute ( Nay ). In Proceedings of the 8th International Multi-Conference on Systems, Signals \& Devices, pp. 3-8.

5. Arel, H. S. (1968). Türk Musikisi Nazariyatı (The Theory of Turkish Music), ITMKD yayınları, no: 2, Hüsnütabiat matbaas1, İstanbul.

6. Arel, H. S. (1951) Arûz Vezinleri ve Musiki Usulleri, Musiki Mecmuası, issues: 40, 41, 43, İstanbul.

7. Atalay, A. (1989). Geleneksel Türk Sanat Musikisinde Perde Dizgeleri. PhD Thesis, Social Sciences. Dokuz Eylul University, İzmir.

8. Atalay, N.B. \& Yöre, S. Türk Sanat Müziği derlemi [Data File]. Retrieved from $<$ www.tsmderlemi.com> (accessed 10.10.2013), Konya, 2011.

9. Ay, G. \& Akkal, L. B. (Eds) (2008), Türk Müziğinde Uygulama-Kuram Sorunlarl ve Çözümleri - Uluslararası Çă̆rılı Kongre Bildiriler Kitabı (Problems And Solutions For Practice And Theory In Turkish Music - International Invited Congress Proceedings), İstanbul Büyükşehir Belediyesi Yayınları, İstanbul, ISBN:9944370721.

10. Ayangil, R. (1998). Türk Musikisinde 'Improvisation’ Biçimleri. Sanat Dünyamız, no: 67, pp. 115-119.

11. Ayangil, R., (2001),’21. Yüzyıl Eşiğinde Türkiyede Müzik Kuramı Çalışmaları”, Musikişinas, no:5, pp. 72-81.

12. Ayangil, R. (2008). Western Notation in Turkish Music. Journal of the Royal Asiatic Society, 18(04), pp. 401-447.

13. Aydemir, M. (2010). Turkish Music Makam Guide. Pan Yayınc1lık.

14. Bardakçı, M. (1986). Maragalı Abdülkadir. Pan Yayınları, İstanbul.

15. Bayraktarkatal, M. E. \& Öztürk, O. M. (2012). Ezgisel Kodların Belirlediği Bir Sistem Olarak Makam Kavramı: Hüseyni Makamı'nın İncelenmesi. Porte Akademik, 3(4), pp. 24.

16. Bektaş, T. (2005). Relationships between Prosodic and Musical Meters in the Beste Form of Classical Turkish Music. Asian Music, 36(1), pp. 1-26.

17. Benetos, E. \& Holzapfel, A. (2013). Automatic Transcription of Turkish Makam Music. In Proceedings of ISMIR - International Conference on Music Information Retrieval, Nov. 4-8th, Curitiba, Brazil.

18. Berkowitz, A. (2010), The improvising mind: Cognition and creativity in the musical moment, Oxford University Press, New York.

19. Bozkurt, B. (2008). An Automatic Pitch Analysis Method for Turkish Maqam Music. Journal of New Music Research, 37(1), pp. 1-13.

20. Bozkurt, B., Gedik, A. C., \& Karaosmanoğlu, M. K. (2008). TMVB: Klasik Türk Müziği İcra Analiz Çalısmaları İçin Bir Veri Bankası. In Ay, G. \& Akkal, L. B. (Eds), Türk Müziğinde 
Uygulama-Kuram Sorunları ve Çözümleri - Uluslararası Çă̆rılı Kongre Bildiriler Kitabı (Problems And Solutions For Practice And Theory In Turkish Music - International Invited Congress Proceedings), İstanbul Büyükşehir Belediyesi Yayınları, İstanbul, ISBN:9944370721.

21. Bozkurt, B., Yarman, O., Karaosmanoğlu, M. K., \& Akkoç, C. (2009). Weighing Diverse Theoretical Models on Turkish Maqam Music Against Pitch Measurements: A Comparison of Peaks Automatically Derived from Frequency Histograms with Proposed Scale Tones. Journal of New Music Research, 38(1), pp. 45-70.

22. Bozkurt, B., Gedik, A. C., \& Karaosmanoğlu, M. K. (2011). An Automatic Transcription System For Turkish Music. Proceedings of Signal Processing and Communications Applications (SIU), pp. 17-20.

23. Bozkurt, B. (2011). Pitch Histogram based analysis of Makam Music in Turkey. Proceedings of Les Corpus de l'oralité, Strasbourg, France.

24. Bozkurt, B. Features for analysis of Makam music. In: Serra X., Rao P., Murthy H., Bozkurt B. editors. Proceedings of the 2nd CompMusic Workshop; 2012 July 12-13; Istanbul, Turkey. Barcelona: Universitat Pompeu Fabra; 2012. pp. 61-65.

25. Can, M. C. (1993) Türk müziğinde makam kavramı üzerine bir inceleme. MS Thesis, Erciyes Üniversitesi, Sosyal Bilimler Enstitüsü.

26. Can, M. C. (2002). Geleneksel Türk Sanat Müziğinde Arel-Ezgi-Uzdilek Ses Sistemi ve Uygulamada Kullanılmayan Bazı Perdeler. G. Ü. Gazi Ĕ̈itim Fakültesi Dergisi, 22(1), pp. 175181.

27. de Cheveigne, A. \& Kawahara, H. (2002). YIN, a fundamental frequency estimator for speech and music. Journal of the Acoustical Society of America, 111(4), pp. 1917-1930.

28. Cohen, D. C. (1964). An Investigation into the Tonal Structure of the Maqamat. Journal of the International Folk Music Council, 16(1964), pp. 102-106.

29. Cohen, D. (1969). Patterns and Frameworks of Intonation. Journal of Music Theory, Vol. 13, No. 1, pp. 66-92.

30. Cohen, L. (1993). The scale representation. IEEE Transactions on Signal Processing, vol. 41, no. 12 , pp. 3275-3292.

31. Cemgil, A. T. (2004). Bayesian Music Transcription. PhD. thesis, Radboud University of Nijmegen.

32. Chrysanthos, P.G.P, (1832). Great Theory of Music, Reprint: The Axion Estin Foundation, Transl: Katy G. Romanou, 2010, ISBN: 0615342590.

33. Conklin, D. (2010). Discovery of distinctive patterns in music. Intelligent Data Analysis, 14, pp. 547-554.

34. Conklin, D. (2001). Representation and discovery of multiple viewpoint patterns. In Proceedings of the International Computer Music Conference, Havana, Cuba, pp. 479-485.

35. Çelik, B. B. (2001) Hızır bin Abdullah'ın Kitabü'l Edvar'l ve Makamların Incelenmesi, MÜ SBE (YDT), İstanbul.

36. Çevikoğlu, T. (2007). Klasik Türk Müziğinin bugünkü sorunları, Proceedings of International Congress of Asian and North African Studies (Icanas 38'), Ankara.

37. Darabi, N., Azimi, N. H., \& Nojumi, H. (2006). Recognition of Dastgah and Maqam for Persian Music with Detecting Skeletal Melodic Models. Proceedings of The second annual IEEE BENELUX/DSP Valley Signal Processing Symposium (SPS-DARTS 2006).

38. Davies, M. E. P. \& Plumbley, M. D. (2007). Context-dependent beat tracking of musical audio. IEEE Transactions on Audio, Speech, and Language Processing, vol. 15, no. 3, pp. 1009-1020.

39. Davis, R. (n.d.) Mode §5: Middle East and Asia:'maqam','makom'. Grove Music Online. Edited by Deane Root. <oxfordmusiconline.com> (accessed 21.04.2013). 
40. Doraisamy, S. (2004). Polyphonic Music Retrieval: The N-gram Approach. PhD Thesis, University of London.

41. Duggan, B., O'Shea, B. \& Cunningham, P. (2008) A System for Automatically Annotating Traditional Irish Music Field Recordings. In Proceedings of Sixth International Workshop on Content-Based Multimedia Indexing, Queen Mary University of London, UK, pp. 25-32.

42. Ederer, E. B. (2011). The Theory and Praxis of Makam in Classical Turkish Music 1910-2010. $\mathrm{PhD}$. Thesis, University of California, Santa Barbara.

43. Elsner, J. \& Pennanen, R. P., (Eds.) (1997). The Structure and Idea of Maqam Historical Approaches, University of Tanpere, DFT Publ., No. 15, Tanpere.

44. Erguner, S. (2007). Ney, 'metod'. İstanbul.

45. Erkut, C., Tolonen, T., \& Karjalainen, M. (1999). Acoustical Analysis of Tanbur, A turkish long-necked lute. In Proceedings of 6th International Congress on Sound and Vibration, pp. 345-352.

46. Erkut, C., Valimaki V. (2000). Model-based sound synthesis of tanbur, a Turkish long-necked lute. In Proceedings of ICASSP, pp. 769-772.

47. Eroy, O. (2010). Tekirdă̆ Bölgesi Çingene Müziklerinde Kullanılan Ezgi Yapılarının Incelenmesi. MS Thesis, Kirıkkale University.

48. Ezgi, S.Z. (1933). Nazarî ve Amelî Türk Mûsıkîsi. Vol. I. Istanbul: Milli Mecmua Matbaası, pp. $8-29$.

49. Feldman, W. (1993). Ottoman Sources on the Development of the Taksîm. Yearbook for Traditional Music, 25, pp. 1-28.

50. Feldman, W. (1996). Music of the Ottoman Court. Berlin: International Institute for Traditional Music.

51. Fremerey, C., Müller, M. \& Clausen, M. (2010). Handling Repeats and Jumps in Scoreperformance Synchronization. In Proceedings of ISMIR - International Conference on Music Information Retrieval, pp. 243-248.

52. Ghrab, A. (2005). The western study of intervals in Arabic Music, from the eighteenth century to the Cairo congress. World of music, 47(3), pp. 55-79.

53. Gedik, A.C., Işıkhan, C., Alpkoçak, A. \& Özer, Y. (2005). Automatic Classification of 10 Turkish Makams. Proc. Int. Cong. on Representation in Music \& Musical Representation, İstanbul.

54. Gedik, A. C., Bozkurt, B. \& Çırak, C. (2009). A Study of Fret Positions of Tanbur Based on Automatic Estimates From Audio Recordings. In Proceedings of CIM09 (Conference on Interdisciplinary Musicology), 26-29 Oct., Paris.

55. Gedik, A. C., \& Bozkurt, B. (2010). Pitch-frequency histogram-based music information retrieval for Turkish music. Signal Processing, 90(4), pp. 1049-1063.

56. Gedik, A. (2012). Automatic Transcription of Turkish Art Music Recordings: A computational ethnomusicology approach. PhD Thesis, Izmir Institute of Technology.

57. Gedik, A. (2013). Similarity Measures for Traditional Turkish Art Music. International Journal of Signal Processing (SPIJ), (7), pp. 52-65.

58. Gomez, E. (2006). Tonal Description of Music Audio Signals. PhD Thesis, Universitat Pompeu Fabra.

59. Gökbudak, R. (2011). Klasik Türk Müziği Çalgllarından Kanun ve Tamburun Tonal Karakteristiklerinin Belirlenmesi. PhD. Thesis, Selçuk Üniversitesi, Eğitim Bilimleri Enstitüsü.

60. Gönül, M. (2010). Nevres Bey’in Ud Taksimleri Analizi ve Ud Eğitimine Yönelik Alıştırmaların Oluşturulması. PhD. Thesis, Selçuk University.

61. Gündüz, G. \& Gündüz, U. (2005). The mathematical analysis of the structure of some songs. Physica A: Statistical Mechanics and its Applications, 357(3-4), pp. 565-592. 
62. Gürmeriç, Ş. (1966). Ders notlarl, (printed lecture notes). İBK Türk Müziği Bölümü Talebe Cemiyeti Neşriyat1, No: 1.

63. Hess, W. (1983). Pitch Determination of Speech Signals: Algorithms and Devices. SpringerVerlag.

64. Hockman, J. A., Davies, M. E. P. \& Fujinaga, I. (2012). One in the Jungle: Downbeat Detection in Hardcore, Jungle, and Drum and Bass. In Proceedings Int. Society for Music Information Retrieval (ISMIR), Porto.

65. Holzapfel, A. \& Stylianou, Y. (2009). Rhythmic similarity in traditional Turkish music. Proceedings of ISMIR, pp. 99-104.

66. Holzapfel, A. (2010). Similarity methods for computational ethnomusicology. PhD. Thesis, University of Crete.

67. Holzapfel, A., Stylianou, Y., Gedik, A. C. \& Bozkurt, B. (2010). Three dimensions of pitched instrument onset detection. IEEE Transactions on Audio, Speech and Language Processing, vol. 18 , no. 6 , pp. 1517-1527.

68. Holzapfel, A., Flexer, A. \& Widmer, G. (2011). Improving tempo-sensitive and tempo-robust descriptors for rhythmic similarity. In Proceedings of SMC 2011, Conference on Sound and Music Computing, Padova, Italy.

69. Holzapfel, A. \& Bozkurt, B. (2012). Metrical strength and contradiction in Turkish makam music. In: Serra X., Rao P., Murthy H., Bozkurt B. editors. Proceedings of the 2nd CompMusic Workshop; 2012 July 12-13; Istanbul, Turkey. Barcelona: Universitat Pompeu Fabra. pp. 79-84.

70. Holzapfel, A. (2013). Tempo in Turkish improvisation. In Proceedings of 3rd Folk music analysis workshop, Amsterdam, Netherlands.

71. Ioannidis, L., Gómez, E., \& Herrera, P. (2011). Tonal-based retrieval of Arabic and MiddleEast music by automatic makam description. In Proceedings of CBMI, pp. 31-36.

72. Kaçar, G. Y. (2002). Yorgo Bacanos' un Ud İcrasındaki Aralıklar ve Arel Ezgi- Uzdilek Ses Sistemi’ne Göre Bir Karşılaştırma. Gazi Eğitim Fakültesi Dergisi, 22(2), pp. 155-161.

73. Karaosmanoğlu, M. K. (2012). A Turkish makam music symbolic database for music information retrieval: SymbTr. In Proceedings Int. Society for Music Information Retrieval (ISMIR), Porto.

74. Karadeniz, M. E. (1980). Türk musikisinin Nazariye ve Esasları. İş Bankası Yayınları, Ankara.

75. Kılınçarslan, H. (2006). Dede Efendi'nin Hüzzam Mevlevi Ayininin Makam, Usul ve Ezgisel Yönden Incelenmesi. MS Thesis, Selçuk University.

76. Koduri, G. K., Gulati, S., Rao, P., \& Serra, X. (2012). Rāga Recognition based on Pitch Distribution Methods. Journal of New Music Research, 41(4), pp. 337-350.

77. Kolinski, M. (1973). A cross-cultural approach to metro-rhythmic patterns. Ethnomusicology, vol. 17, no. 3, pp. 494-506.

78. Lartillot, O., \& Ayari, M. (2009). Segmentation of Tunisian Modal Improvisation: Comparing Listeners' Responses with Computational Predictions. Journal of New Music Research, 38(2), pp. 117-127.

79. Lartillot, O., \& Ayari, M. (2011). Cultural impact in listeners' structural understanding of a Tunisian traditional modal improvisation, studied with the help of computational models. Journal of interdisciplinary music studies, 5(1), pp. 85-100.

80. Lartillot, O., \& Ayari, M. (2012). An Integrated Framework for Transcription, Modal and Motivic Analysis of Maqam Improvisation. In: Serra X., Rao P., Murthy H., Bozkurt B. editors. Proceedings of the 2nd CompMusic Workshop; July 12-13; Istanbul, Turkey. Barcelona: Universitat Pompeu Fabra. pp. 32-37.

81. Lerdahl, F. \& Jackendoff, R. (1983), A generative theory of tonal music, MIT Press, Cambridge. 
82. List, G. (1974), The reliability of transcription. Ethnomusicology, 18(3), pp. 353-377.

83. Marcus, S. (2001). Rhythmic modes in middle-eastern music. in Garland Encyclopedia of World Music, Volume 6: Middle east. Virginia Danielson and Scott Marcus and Dwight Reynolds, Editors, pp. 89-92.

84. Nagavi, T. C. \& Bhajantri, N. U. (2011). Overview of automatic Indian music information recognition, classification and retrieval systems. International Conference on Recent Trends in Information Systems, pp. 111-116.

85. Nakhjavani, S. (2010). Comparison of Iranian and Turkish Music Makams. PhD Thesis, Istanbul Technical University.

86. Özaslan, T. H., Serra, X. \& Arcos, J. L. (2012). Characterization of Embelishments in Ney Performances of Makam Music in Turkey. In Proceedings Int. Society for Music Information Retrieval (ISMIR), Porto.

87. Özbek, M. E. \& Savac1, F. A. (2009). Classification of Turkish Musical Instruments. Proceedings IEEE 17th Signal Processing and Communications Applications Conference, SIU, Antalya, pp. 9-11.

88. Özek, E. (2011) Türk müziğinde çeşni kavramı ve icra teori faklılıklarının bilgisayar ortamında incelenmesi, PhD. Thesis, Haliç University.

89. Özkan, İ. H. (2006). Türk Musikisi Nazariyatı ve Usulleri Kudüm Velveleleri. Istanbul: Ötüken Neşriyat.

90. Öztürk, O. M. (2006). Zeybek Kültürü ve Müziği. Istanbul: Pan Yayıncılık.

91. Öztürk, O. M. (2011). Turkish Modernisation and Makam Concept: Some determinations on two musical systems, ICTM Yearbook.

92. Pikrakis, A., Antonopoulos, I., Theodoridis, S. \& Theodoridis, S. (2004). Music meter and tempo tracking from raw polyphonic audio. in Proceedings of the International Society for Music Information Retrieval Conference (ISMIR), Barcelona, pp. 301-304.

93. Pennanen, R. (2008). Lost in scales: Balkan folk music research and the Ottoman legacy. Muzikologija, 10(8), pp. 127-147.

94. Popescu-Judetz, E. (1996). Meanings in Turkish Musical Culture. Istanbul: Pan Yay1nc1lık.

95. Powers, H. (1988). First Meeting of the ICTM Study Group on Maqam. Yearbook For Traditional Music, 20, pp. 199-218.

96. Powers, H. S. \& Wiering, F. (n.d.). Mode §1: The term. Grove Music Online. Edited by Deane Root. <oxfordmusiconline.com> (accessed 21.04.2013).

97. Salamon, J. \& Gomez, E. (2012). Melody Extraction From Polyphonic Music Signals Using Pitch Contour Characteristics. IEEE Transactions on Audio, Speech, and Language Processing, 20(6), pp. 1759-1770.

98. Serra, X. (2011). A Multicultural Approach in Music Information Research. In Proceedings of the 5th International Society for Music Information Retrieval Conference (ISMIR), Miami, pp. 151-156.

99. Serra, X., Magas, M., Benetos, E., Chudy, M., Dixon, S., Flexer, A., Gómez, E., Gouyon, F., Herrera, P., Jordà, S., Paytuvi, O., Peeters, G., Schlüter, J., Vinet, H. \& Widmer, G. (2013). Roadmap for Music Information Research. Creative Commons BY-NC-ND 3.0 license.

100.Serra, X. (2013). Exploiting Domain Knowledge in Music Information Research. In Proceedings of Stockholm Music Acoustics Conference and Sound and Music Computing Conference, Stockholm, pp. 3-6.

101.Sordo, M., Koduri G. K., Şentürk, S., Gulati, S., Serra, X. (2012) A Musically aware system for browsing and interacting with audio music collections. In: Serra X., Rao P., Murthy H., Bozkurt B. editors. Proceedings of the 2nd CompMusic Workshop; July 12-13; Istanbul, Turkey. Barcelona: Universitat Pompeu Fabra. pp. 20-24. 
102. Sethares, W. A. (2005). Tuning Timbre Spectrum Scale, Second Edition, Springer Verlag.

103. Signell, K. (1974). Esthetics of Improvisation in Turkish Art Music. Asian Music, 5(2), pp. 4549.

104.Signell, K. L. (2008). Makam: Modal Practice in Turkish Art Music. Usul editions.

105.Six, J. \& Cornelis, O. (2011). Tarsos-A Platform to Explore Pitch Scales in Non-Western and Western Music. Proceedings of the Int. Society for Music Information Retrieval (ISMIR), Miami, pp. 169-174.

106. Srinivasamurthy, A., Holzapfel, A. \& Serra, X. (2013). In search of automatic rhythm analysis methods for Turkish and Indian art music. Submitted to Journal of New Music Research.

107.Stubbs, F. W. (1994). The art and science of taksim: an emprical analysis of traditional improvisation from 20th century Istanbul. $\mathrm{PhD}$. Thesis, Wesleyan University.

108. Sümbüllü, H. T., Albuz, A. (2011). Türk sanat müziği dizilerinin bilgisayar destekli makamsal analizi. Uluslararası Insan Bilimleri Dergisi. 8:1, pp. 145-198.

109.Şentürk, S. (2011). Computational Modeling of Improvisation in Turkish Folk Music using Variable-length Markov Models. Georgia Institute of Technology.

110. Şentürk S, Holzapfel A. \& Serra X. (2012) An Approach for linking score and audio recordings in Makam music of Turkey. In: Serra X., Rao P., Murthy H., Bozkurt B. editors. Proceedings of the 2nd CompMusic Workshop; July 12-13; Istanbul, Turkey. Barcelona: Universitat Pompeu Fabra. pp. 95-106.

111.Tan, O. (2011). Ney açkısının tarihi ve teknik gelişimi. PhD. Thesis, Istanbul Technical University.

112. Tanrikorur, C. (2003). Osmanlı Dönemi Türk Musikisi. Dergah Yayınları, İstanbul.

113. Tarikci, A. (2010). Analysis of Turkish Art Music Songs via Fractal Dimension. PhD. Thesis. Department of Physics, Middle East Technical University, Ankara.

114. Temperley, D. \& Marvin, E. W. (2008). Pitch-Class Distribution and the Identification of Key. Music Perception, 25(3), pp. 193-212.

115. Touma, H. H. (1971). The maqam phenomenon: An improvisation technique in the music of the Middle East. Ethnomusicology, 15(1), pp. 38-48.

116. Tura, Y. (1988). Bağlamadaki perde bağlarının nisbetleri ve bunlardan doğan ses sistemi. In Türk musikisinin meseleleri, Pan Yayıncıl1k, İstanbul, pp. 158 - 168.

117. Tzanetakis, G., Kapur, A., Schloss, W. A. \& Wright, M. (2007). Computational ethnomusicology. Journal of interdisciplinary music studies, 1(2), pp. 1-24.

118. Tzanetakis, G., Ermolinskyi, A. \& Cook, P. (2003). Pitch Histograms in Audio and Symbolic Music Information Retrieval. Journal of New Music Research, 32(2), pp. 43-152.

119.Ünal, E., Bozkurt, B. \& Karaosmanoğlu, M. K. (2013). A hierarchical approach to makam classification in Turkish makam music, using symbolic data, Accepted for Journal of New Music Research.

120. Wright, O. (1990). "Çargâh” in Turkish Classical Music: History versus Theory. Bulletin of the School of Oriental and African Studies, University of London, 53(2), pp. 224-244.

121. Yarman, O. (2002). A Short History of Turkish Mûsıî. Folk, pp. 1-8.

122. Yarman, O. (2007a). A Comparative Evaluation of Pitch Notations in Turkish Makam Music. Journal of interdisciplinary music studies, 1(2), pp. 43-61.

123. Yarman, O. (2007b). 79-tone Tuning \& Theory for Turkish Maqam Music 79-tone Tuning \& Theory for Turkish Maqam Music. Social Sciences. PhD. Thesis, Istanbul Technical University.

124. Yavuzoğlu, N. (2008). 21. Yüzyılda Türk Müziği Teorisi. Pan Yayınc1lık, İstanbul.

125. Yekta, R. (1924). Musiki Nazariyatı (Music Theory). İstanbul, (reprint: Musikişinas, İstanbul Bahar 1997). 
126.Zannos, I. (1990). Intonation in Theory and Practice of Greek and Turkish Music. Yearbook for Traditional Music, 22(1990), pp. 42-59.

127.Zeren, A. (2003). Müzik Sorunlarımız Üzerine Araştırmalar, Pan Yayıncılık, İstanbul. 